2015-10

\title{
Green supply chain management enablers: Mixed methods research
}

\author{
Dubey, $\mathrm{R}$
}

http://hdl.handle.net/10026.1/5541

10.1016/j.spc.2015.07.001

Sustainable Production and Consumption

Elsevier BV

All content in PEARL is protected by copyright law. Author manuscripts are made available in accordance with publisher policies. Please cite only the published version using the details provided on the item record or document. In the absence of an open licence (e.g. Creative Commons), permissions for further reuse of content should be sought from the publisher or author. 
Elsevier Editorial System(tm) for Sustainable Production and Consumption Manuscript Draft

Manuscript Number: SPC-D-15-00071R1

Title: Green Supply Chain Management Enablers: Mixed Methods Research

Article Type: SI: Emerging Economies

Keywords: Green Supply Chain Management (GSCM), Environmental Management (EM), Institutional Theory, Interpretive Structural Modeling (ISM), MICMAC analysis.

Corresponding Author: Prof. Angappa Gunasekaran, PhD

Corresponding Author's Institution: University of Massachusetts Dartmouth

First Author: Rameshwar Dubey, PhD

Order of Authors: Rameshwar Dubey, PhD; Angappa Gunasekaran, PhD; Thanos Papadoupoulos, PhD; Steve Childe, $\mathrm{PhD}$

Abstract: This paper contributes to the literature on green supply chain management (GSCM) by arguing for the use of mixed methods for theory building. The literature has identified antecedents and enablers for the adoption of GSCM practices. Nevertheless, there is relatively little research on building robust methodological approaches and techniques that take into account the dynamic nature of green supply chains. To address this gap, the paper firstly reviews systematically the literature on GSCM enablers; secondly, it argues for the use of mixed methods research to address questions related to GSCM enablers; thirdly, it uses interpretive structural modeling (ISM), MICMAC analysis, and confirmatory factor analysis (CFA) to illustrate the application of mixed methods in GSCM by testing a model on the enablers of GSCM; and fourthly, highlights the influence of enablers including, inter alia, top management commitment, institutional pressures, supplier and customer relationship management on financial and environmental performance. Finally, we conclude with limitations and further research directions. 


\title{
Green supply chain management enablers: Mixed methods research
}

\author{
$\underline{\text { Research Highlights }}$
}

- This paper contributes to the literature on green supply chain management (GSCM) by arguing for the use of mixed methods for theory building.

- There is relatively little research on building robust methodological approaches and techniques that take into account the dynamic nature of green supply chains.

- To address this gap, the paper firstly reviews systematically the literature on GSCM enablers; secondly, it argues for the use of mixed methods research to address questions related to GSCM enablers; thirdly, it uses interpretive structural modeling (ISM), MICMAC analysis, and confirmatory factor analysis (CFA) to illustrate the application of mixed methods in GSCM by testing a model on the enablers of GSCM; and fourthly, highlights the influence of enablers including, inter alia, top management commitment, institutional pressures, supplier and customer relationship management on financial and environmental performance.

- Finally, we conclude with limitations and further research directions. 


\title{
Green supply chain management enablers:
}

\section{Mixed methods research}

\author{
Rameshwar Dubey \\ Symbiosis Institute of Operations Management \\ (Constituent of Symbiosis International University) \\ Plot No. A-23, Shravan Sector \\ CIDCO \\ New Nashik-422008 \\ India
}

Cell. No. +918600417738

Tel. No. +91-253-2379960 Ext. No.39

E-mail: rameshwardubey@gmail.com

Angappa Gunasekaran*

Charlton College of Business

University of Massachusetts Dartmouth

North Dartmouth, MA 02747-2300

USA

Tel: (508) 999-9187

Fax: (508) 999-8646

E-mail: agunasekaran@umassd.edu

*Corresponding Author

Thanos Papadopoulos

Sussex School of Business, Management and Economics

University of Sussex

Sussex House, Falmer

Brighton, BN1 9RH

United Kingdom

Tel: +441273678522

E-mail: Athanasios.Papadopoulos@sussex.ac.uk

$$
\begin{gathered}
\text { Steve Childe } \\
\text { Department of Engineering, } \\
\text { University of Exeter, } \\
\text { Exeter EX4 4QF } \\
\text { United Kingdom } \\
\text { s.j.childe@exeter.ac.uk }
\end{gathered}
$$




\section{Green supply chain management enablers: \\ Mixed methods research}

\section{Abstract}

This paper contributes to the literature on green supply chain management (GSCM) by arguing for the use of mixed methods for theory building. The literature has identified antecedents and enablers for the adoption of GSCM practices. Nevertheless, there is relatively little research on building robust methodological approaches and techniques that take into account the dynamic nature of green supply chains. To address this gap, the paper firstly reviews systematically the literature on GSCM enablers; secondly, it argues for the use of mixed methods research to address questions related to GSCM enablers; thirdly, it uses interpretive structural modeling (ISM), MICMAC analysis, and confirmatory factor analysis (CFA) to illustrate the application of mixed methods in GSCM by testing a model on the enablers of GSCM; and fourthly, highlights the influence of enablers including, inter alia, top management commitment, institutional pressures, supplier and customer relationship management on financial and environmental performance. Finally, we conclude with limitations and further research directions.

Key Words: Green Supply Chain Management (GSCM), Environmental

Management (EM), Institutional Theory, Interpretive Structural Modeling (ISM), MICMAC analysis.

\section{Introduction}

There is growing trend among the companies to link green practices with their corporate strategies (see Gunasekaran and Gallear, 2012; Sarkis et al. 2011). Green manufacturing, or more precisely the green supply chain, has attracted interest among management researchers, environmentalists and practitioners in the last decade (Gunasekaran and Spalanzani, 2012; Brockhaus et al. 2013). Realising the need to incorporate sustainability and the triple bottom line (Kleindorfer et al., 2005) as part of their strategic intent, companies focus on assessing the economic, environmental, and social impact of their activities and highlighting the relationship between sustainability and performance (Leppelt et al., 2013; Green et al., 2012; Burritt and Schaltegger, 2012; Subramanian and Gunasekaran, 2015). Scholars have included the social and environmental measures in their models (e.g. Bell et al. 2012;Giovanni, 2012; Hollos et al., 2012; Gimenez et al.2012; Paulraj and de Jong, 2011; Awaysheh and Klassen, 2010), looking at, for 
instance, the effect of internal or external environmental practices on the triple bottom line (Giovanni, 2012) and economic performance (Giovanni and Vinzi, 2012) or the role of supplier collaboration in sustainable performance (Hollos et al., 2012).

There is a rich body of literature on enablers of GSCM implementation and their interrelationships (Ali and Govindan, 2011; Large and Thomsen, 2011; Mathiyazhagan et al. 2013) highlighting the role of GSCM in achieving sustainability

(Hsu et al., 2013). The majority of these GSCM studies, however, use either quantitative approaches and methodologies by collecting and analysing large samples and testing hypotheses and models, or qualitative case studies following grounded theory inspired approaches (Binder and Edwards, 2010; Soltani et al., 2014). Other scholars claim that the current literature in the field of operations and supply chain management has extensively used deductive, big data, "empirical research" (Markman and Krause, 2014). Although the deductive approach provides reliable answers to the research questions, at the same time empirical research does narrow the scope (Markman and Krause, 2014). Meredith (1998) argues that case study is a powerful approach for building theories, in comparison to rationalist approach which is sometimes referred to as traditionalist or quantitative research. The argument offered by Meredith (1998) is that most of the times the papers published in reputable journals which have used a rationalist approach are less well understood by the readers.

In recent years the use of the case study approach has attracted interest in the operations and supply chain management community (Ketokivi and Choi, 2014). Pagell and Wu (2009) have used 10 cases to build comprehensive theory. However, in spite of their merits, case studies have significant demerits as identified by Meredith (1998). Scholars have criticized the case study research approach on the grounds of "ambiguity of inferred hypotheses" and the "selective bias" (Bitektine, 2008: 161; Barratt et al., 2011), and in that there is risk that the researcher would look for data that fits hypotheses stated a priori (Barratt et al., 2011). These criticisms have stemmed mainly from scholars who are not familiar with qualitative methods (Bitektine, 2008; Roth, 2007). However, rather than continuing the never-ending debate between quantitative or qualitative research, in this paper we argue for the use of mixed-method research which may employ both qualitative and quantitative methods in order to build theory, in the context of GSCM, driven by the endorsement of scholars to build robust methodological approaches and techniques that consider the dynamic environment of OM and SCM (and in our case GSCM). Furthermore, there is need for more studies looking at green supply chain initiatives in emerging economies, which "is still an underresearched area" (Hsu et al., 2013: p. 656). 
To elaborate on our argument, we: (i) undertake an extensive literature review and identify key enablers of GSCM practices; (ii) understand the relationship among enablers of GSCM practices through the adoption of interpretive structural modelling and develop an interpretive structural model (ISM); (iii) provide a four-category taxonomy of enablers based on their dependence and driving power (i.e. MICMAC analysis); (iv) use the MICMAC analysis to develop a theoretical GSCM framework; and ( $v$ ) validate the proposed GSCM theoretical framework using confirmatory factor analysis (CFA).

The rest of the paper is organized as follows. In the following section we outline our systematic literature review. In the third section we describe our research theoretical framework and research hypotheses. In section four, we detail our research design. Section five discusses CFA analysis and PLS-SEM hypotheses test output. In section six, we conclude our research and outline further research directions.

\section{Literature Review}

We conducted our systematic literature review (SLR) to identify the key enablers of GSCM and their interrelationships, following the principles set out by Tranfield et al. (2003), Rowley and Slack (2004) and were inspired by other prominent scholars (Burgess et al., 2006; Cousins et al., 2006) that have been used in recent reviews by Chen et al. (2014) and Gunasekaran et al. (2015). SLR is a quite popular methodology in medical science, however in recent years it has seen significant growth in management fields (Lightfoot et al. 2013), to synthesize and organize research findings from multiple studies. In this process we have adhered to the principles outlined by Tranfield et al. (2013) i.e. transparent, replicable and rational. We have derived publication data from the following databases: ProQuest, Science Direct, EBSCO, SCOPUS, Emerald, Springer, Inspec, and Compendex. Our search was based on the following terms and strings: 'green supply chain', 'green manufacturing', 'sustainability', 'antecedents', and 'enablers'. During the search activity we had access to reputable journals in the field of operations and supply chain management, management research methods, reports, and edited books. In order to assure ourselves that we were not missing any relevant work(s), we also used Google Scholar. This process identified 284 seemingly relevant items as a basis for further analysis. All articles were considered to be representative of the current body of knowledge associated with the GSCM, green manufacturing and ISM modeling.

We followed Chen et al. (2010) and subsequent studies (Merali et al., 2012) in that we conducted a manual scan and analysis of all the abstracts and a selection of the highly cited and review 
papers. In this vein, we interpreted and highlighted themes and features within the extant GSCM literature. The thematic analysis involved a detailed review of the content of each research article. To do this we created a coding frame to catalogue the textual content and brief summaries of each paper. This coding frame emulated a tree structure with over 40 initial variables under 9 constructs. The coding framework evolved inductively as the analysis work progressed. This process yielded substantial articles that we have included in our research.

\subsection{Classification of GSCM enablers}

We have classified key enablers of GSCM practices, based on extensive literature review as shown in Table 1. The enablers are discussed in the next subsections.

Table 1: Enablers of GSCM practices

\begin{tabular}{|c|c|}
\hline Enablers & References \\
\hline Total Quality Management & $\begin{array}{l}\text { Pauli 1997; Prajogo et al. 2012; Pereira-Moliner et al. 2012; } \\
\text { Gavronski et al. 2011; Jabbour et al. 2014; Bag and Anand, 2014; Dubey et al. } \\
\text { 2014; Dubey et al. } 2015 .\end{array}$ \\
\hline $\begin{array}{l}\text { Supplier Relationship } \\
\text { Management }\end{array}$ & $\begin{array}{l}\text { Bierma and Waterstraat 1999; Vachon and Klassen 2006; Zhu et al. 2008; Lee } \\
\text { and Klassen, 2008; Hsu and Hu 2009; Bai and Sarkis 2010; Ku et al. 2010; Testa } \\
\text { and Iraldo 2010; Hoof and Lyon 2013; Kumar et al. 2014; Bag and Anand, } \\
\text { 2014; Dubey et al. 2014; Dubey et al. 2015. }\end{array}$ \\
\hline Green technology adoption & $\begin{array}{l}\text { Sikdar and Howell 1998; Nguene et al. 2011; Zhang et al. } \\
\text { 2013; Hoof and Lyon 2013; Bag and Anand, 2014; Akman and } \\
\text { Mishra, } 2015\end{array}$ \\
\hline Institutional pressures & $\begin{array}{l}\text { Zhu et al. 2005; Tsoulfas and Pappis 2006; Zhu et al. 2008; Sarkis et al.2011; } \\
\text { Singh et al.2012; Dubey et al. } 2015 .\end{array}$ \\
\hline Top management & Siaminwe et al. 2005; Stone 2006; Berkel 2007; Zhu et al. \\
\hline commitment & $\begin{array}{l}\text { 2008; Deif 2011; Despeisse et al. 2012; Law and Gunasekaran, } \\
\text { 2012; Singh et al.2012; Dues et al. 2013; Hoof and Lyon 2013; } \\
\text { Liang et al., 2007; Gattiker and Carter, 2010; Foerstl et al., } \\
\text { 2015; Abdulrahman et al., 2014; Jabbour and Jabbour, } 2015\end{array}$ \\
\hline Reduction in carbon emissions & $\begin{array}{l}\text { Zhu and Sarkis, 2004; Wagner and Schaltegger, 2004; } \\
\text { Chaabane et al. 2012; Zhu and Geng, 2013; } \\
\text { Zhang and Wang, } 2014\end{array}$ \\
\hline $\begin{array}{l}\text { Customer Relationship } \\
\text { Management }\end{array}$ & $\begin{array}{l}\text { Seuring et al. 2004; Zhu et al. 2008; Lee and Klassen, 2008; } \\
\text { Baines et al.2012; Jayaram and Abittathur, } 2015\end{array}$ \\
\hline
\end{tabular}




\begin{tabular}{|l|l|}
\hline Increase in Market Share & $\begin{array}{l}\text { Hervani et al. 2005; González-Benito and González-Benito, } \\
\text { 2005; Zhu et al.2005; Zhu and Sarkis, 2006; Farish 2009; } \\
\text { Franchetti et al. 2009; Deif 2011; Buyukozkan and Cidci, 2012; Murovec et al. } \\
\text { 2012; Prajogo et al. 2012; Pereira-Moliner et al. 2012; Gunasekaran and } \\
\text { Spalanzani, 2012; Dues et al. } \\
\text { 2013; Gavronski et al. 2011. }\end{array}$ \\
\hline Profitability & $\begin{array}{l}\text { González-Benito and González-Benito, 2005; Deif 2011; Murovec et al. 2012; } \\
\text { Prajogo et al. 2012; Pereira-Moliner et al. 2012; Gunasekaran and Spalanzani, } \\
\text { 2012; Dues et al. 2013; Gavronski et al. 2011. }\end{array}$ \\
\hline
\end{tabular}

Total quality management (TQM) - Kitazawa and Sarkis (2000) have argued that TQM implementation in any organization helps with waste minimization. Furthermore, PereiraMoliner et al. (2012), in their study in the hotel industry, have identified the relationship between quality management and environmental management, arguing that the implementation of quality management practices enables the development of skills that are needed for environmental management. Finally, Jabbour et al. (2014) argued the role of quality management as an antecedent of maturity in environmental management, which influences the adoption of GSCM practices and performance. Dubey et al. (2015) further supported this argument, suggesting that those firms implementing TQM have achieved superior environmental performance.

Supplier relationship management (SRM) - It is very essential for an organization that aims to adopt green supply chain practices to align its suppliers with its business objectives. Regular training by organizations to their suppliers is essential for proper understanding by the suppliers how to become 'cleaner' and 'greener'. Recent research findings further supports our generalization regarding supplier relationship management as an important enabler of GSCM (Bai and Sarkis 2010; Ku et al. 2010; Testa and Iraldo 2010; Hoof and Lyon 2013; Kumar et al. 2014; Bag and Anand, 2014; Dubey et al. 2014; Dubey et al. 2015). Vachon and Klassen (2006) have illustrated the importance of collaborating with suppliers for GSCM. In particular they argued that inter-organizational collaboration, including suppliers, contributes to manufacturing performance. However, collaboration downstream of the supply chain - with customers - may bring mixed outcomes. Upstream practices are hence more closely associated to process-based performance, whereas downstream practices are related to product-based performance. In a recent study, Dubey et al. (2015) argued that supplier relationship management has a partial mediation effect on environmental performance. They have that TQM is mediating between 
supplier relationship management and environmental performance. Hence, we further argue that supplier relationship management is one of the important enablers of GSCM implementation.

Green technology adoption (GTA) - Green technology is a vital parameter in Sustainable Manufacturing and efforts has to be put into improving on technology continuously by improving process efficiency. Sikdar and Howell (1998) argued the importance of use of green technology or environmentally-friendly technology to reduce the negative impacts of industrial waste on the planet. Further there is an extensive list of research work that supports the use of green technology in GSCM network (e.g. Nguene et al. 2011; Zhang et al. 2013; Hoof and Lyon 2013; Bag and Anand, 2014; Dubey et al. 2014). In a recent study, Akman and Mishra (2015) discuss the diversity between public and private sectors in GTA using the technology acceptance model. In particular, they suggest differences between the influence of perceived ease of use on perceived usefulness and attitude towards use between public and private sector. They emphasize that no matter if GTA has been acknowledged as being influential to performance, there are concerns by public-sector professionals regarding environmental sustainability by the use of IT.

Institutional Pressures (IP) - Recent years have seen an increasing role of institutional theory in the fields of OM and SCM (Kauppi 2013). According to Scott (2008), institutional theory suggests that external forces motivate firms to undertake similar strategic actions. Under institutional theory, firms are not only profit-seeking entities, but also recognize the importance of achieving social legitimacy. Institutional theory has two main forms, an economic variant and a social variant (Ketokivi and Schroeder 2004). The mechanisms identified are coercive, mimetic and normative, which lead towards institutional isomorphism (DiMaggio and Powell 1983). The coercive mechanism consists of formal or informal pressures created on firms by other firms on which they are dependent and by expectations from society (Kauppi 2013; DiMaggio and Powell 1983). For example, government regulations play a crucial role in adjusting supply chain activities to be greener. ISO 14001 certification helps organizations to improve their existing environmental standard and waste reduction. Emission norms set by government regulate the emission limits of both petrol and diesel engines to protect the environment against emission of excess carbon content into the atmosphere. More stringent norms are needed though to regulate the increasing issue of global warming. Many organizations involved in exports have started adopting the green practices in their supply chain as part of the competition with foreign domestic players. The marketing strategies have also begun to showcase them as environmentally-friendly organizations to gain customer attention. Zhu et al. (2005) argued the role of institutions in the successful implementation of GSCM practices. Dubey et al. (2015) have further argued the 
moderating role played by institutional pressures on SRM and TQM, which help enhance environmental performance.

Top management commitment (TMC) - Top management commitment is vital to organizations and supply chain partners aiming to implement green and sustainable practices (Liang et al., 2007; Gattiker and Carter, 2010; Foerstl et al., 2015). The importance of top management beliefs, practices, and commitment has been hence highlighted in the literature (Abdulrahman et al., 2014; Bag and Anand, 2014; Jabbour and Jabbour, 2015). Hence, without support from higher management it is impossible to make use of cleaner and greener resources in the supply chain. Management should be proactive rather than reactive in going green in every aspect possible. Recent research supports our assumption that top management commitment is an important enabler (Deif 2011; Despeisse et al. 2012; Law and Gunasekaran, 2012; Singh et al.2012; Dues et al. 2013; Hoof and Lyon 2013; Dubey et al. 2015).

Reduction in carbon emissions (RCE) - In our study, we consider reduction in carbon emissions as one of the enablers of the GSCM practices. In recent research scholars have investigated how an organization under the influence of institutional pressures may pursue various activities to reduce carbon emissions (Zhu and Sarkis, 2004; Wagner and Schaltegger, 2004; Schoenherr, 2012; Zhang and Wang, 2014). Zhu and Geng (2013) identified the drivers and barriers that come to the fore in the collaboration of Chinese manufacturers with their suppliers and customers to meet carbon emission goals. Chaabane et al. (2012) studied the tradeoffs between economic and environmental goals under various strategies in the aluminum industry and called for better harmonization between current legislation and emission trading schemes in order for an environmental strategy to be realized. Zhang and Wang (2014) have looked into carbon emission reduction (CER) within industrial chains and have identified the lack of infrastructure as the main barrier that negatively influences inter-firm collaborations for CER. They also illustrated that CER impacts positively economic performance, but also relates to improved environmental performance.

Customer relationship management (CRM) - Customers are becoming more educated and conscious about the environmental degradation and want the product they buy to be environment friendly. They may also want the final disposal and decomposition to be done without harming the environment. Customers in developed countries are more conscious on this issue than Indian customers. Hence the companies that export their products adhere more to adopting green practices in their supply chain as required by their customers. The recent research indicates that interface with customers provides valuable input, which helps to implement GSCM in an organization (Seuring et al. 2004; Zhu et al. 2008; Baines et al. 2012). Zhu et al. (2008) discuss 
the capabilities of GSCM in Chinese firms between different contexts and call for greater collaboration between firms and customers for adoption of GSCM practices. In a recent study, Jayaram and Abittathur (2015) focused on the emerging economy of India and proposed a model that links environmental policies to customer actions and sustainability strategies. They found that managing customers in relation to green design, product recovery and reverse logistics are crucial for achieving GSCM. Hence, the management of customer relationships is an important enabler for GSCM implementation.

Increase in market share (MS) - Increase in market share has been identified in the literature as one of the aims of GSCM (e.g. Gavronski et al. 2011; Prajogo et al. 2012; Pereira-Moliner et al. 2012; Gunasekaran and Spalanzani, 2012). Hervani et al. (2005) pointed out how customer satisfaction resulting from GSCM practices may enhance loyalty feelings towards an organization, which in turn gets translated into an increase in market share as seen in many cases. Ahi and Searcy (2013), in their review of definitions for green and sustainable supply chain management, suggest that GSCM is directly related with aims of firms to achieve greater market share, building on definitions by Zhu et al. (2005) and Buyukozkan and Cidci (2012).

Increase in profitability (Profitability) - The GSCM practices and increased focus on R's (i.e. reduction, reuse, reselling, repair, recycling, refurbishing, remanufacturing and reverse logistics) can help an organization achieve their bottom line (i.e. profitability) while at the same time the market share also increases due to enhanced customer satisfaction and green experience. The recent research further indicates that those organizations that have embraced GSCM as their corporate strategy have improved their bottom line (i.e. Gavronski et al. 2011; Murovec et al. 2012; Prajogo et al. 2012; Pereira-Moliner et al. 2012; Gunasekaran and Spalanzani, 2012; Dues et al. 2013). Zhu and Sarkis (2004) have related the adoption of green supply chain practices to performance, whereas in later studies this argument was further enhanced (Tate et al., 2010; Hofer et al., 2012).

\subsection{Reflection on trends in methodology and theory building}

In this section we discuss the attempts by scholars to build theory in GSCM.

Any attempt to build theory needs to answer fundamental questions (Sushil, 2012; Whetten, 1989), related to "what", "how" and "why" (Whetten, 1989). In this vein, studies suggesting frameworks as a way of advancing theory would need to provide answers regarding the basic constructs, dimensions or elements constituting the framework (what); hypothesized relationships among the research variables (how); and causal thinking (why) to explain the linkages among constructs that are envisaged as hypotheses. The questions of 'what', 'how' and 'why' may either be obtained from literature using past theories or models already validated by 
other researchers, or may be explored using grounded theory (Strauss and Corbin, 1990; Binder

and Edwards, 2010; Soltani et al., 2014) in areas where adequate conclusive literature is not available. The theory seeks the inputs from field in terms of qualitative views from working professionals/ experts based on their experience in the problem domain under investigation or by using case experiences in an inductive manner (Sushil, 2012; Strauss and Corbin, 1990). Researchers may find it easy to answer "what" either from literature or field or both so as to identify key variables as the starting point in any research query. They may use past theories to back "how" and "why". If however content analysis is used to identify elements or themes, answers to "how" and "why" are difficult to be provided in terms of relationships between elements and themes, and are usually portrayed on a case-to-case basis.

Drawing on the literature review from the previous section, in Table 2 we provide examples of studies that propose a theoretical framework based on literature review and adopt statistical techniques or multiple criteria decisionmaking (MCDM) tools or contextual method such as ISM or Graph Theory and Matrix Approach.

Table 2: Examples of GSCM theory building and relevant methodologies

\begin{tabular}{|c|c|c|}
\hline References & Theory building & Methodology \\
\hline Mathiyazhagan et al. 2014 & $\begin{array}{l}65 \text { key drivers to GSCM implementation, } \\
\text { grouped into six broad categories. }\end{array}$ & $\begin{array}{l}\text { Extends institutional theory and } \\
\text { combines it with analyzing } \\
\text { barriers to GSCM using analytic } \\
\text { hierarchy process (AHP). }\end{array}$ \\
\hline Mathiyazhagan et al. 2013 & $\begin{array}{l}26 \text { constructs - barriers of GSCM } \\
\text { implementation. }\end{array}$ & $\begin{array}{l}\text { Interpretive structural model } \\
\text { (ISM) methodology and } \\
\text { MICMAC analysis. }\end{array}$ \\
\hline Muduli et al. 2013 & $\begin{array}{l}\text { Barriers of GSCM practices in Indian mining } \\
\text { sector. }\end{array}$ & $\begin{array}{l}\text { Graph Theory and Matrix } \\
\text { Approach (GTMA). }\end{array}$ \\
\hline Jabbour et al. 2013 & $\begin{array}{l}\text { Size of the company, previous experience } \\
\text { and hazardous inputs are positively } \\
\text { correlated with GSCM practices adoption. }\end{array}$ & $\begin{array}{l}\text { In this article researchers have } \\
\text { used statistical analysis of } \\
\text { variance and regression } \\
\text { methods. }\end{array}$ \\
\hline
\end{tabular}




\begin{tabular}{|l|l|l|}
\hline Muduli et al.2013a & $\begin{array}{l}\text { Interaction among human behaviors in } \\
\text { green supply chain network. }\end{array}$ & $\begin{array}{l}\text { Interpretive structural model } \\
\text { (ISM) methodology }\end{array}$ \\
\hline Yusuf et al.2013 & $\begin{array}{l}\text { Impact of sustainable practices on business } \\
\text { performance. }\end{array}$ & $\begin{array}{l}\text { Statistical analysis using } \\
\text { secondary data. }\end{array}$ \\
\hline Ghosh and Shah, 2012 & $\begin{array}{l}\text { Green policies across the supply chain } \\
\text { network. }\end{array}$ & Game theory. \\
\hline Wang et al.2012 & $\begin{array}{l}\text { Model extrapolating enablers of } \\
\text { GSCM and their uncertainty nature. }\end{array}$ & Fuzzy AHP. \\
\hline Zailani et al. 2012 & $\begin{array}{l}\text { Framework outlining sustainable purchasing } \\
\text { and sustainable packaging for better } \\
\text { environmental, economic, social, and } \\
\text { operational performance. }\end{array}$ & $\begin{array}{l}\text { Exploratory factor analysis } \\
\text { followed by regression analysis. }\end{array}$ \\
\hline Giovanni and Vinzi, 2012 & $\begin{array}{l}\text { Relationship between EM, types of } \\
\text { environmental } \\
\text { performance. }\end{array}$ & $\begin{array}{l}\text { Stractices, } \\
\text { for testing research hypotheses. } \\
\text { the social and environmental outcomes of } \\
\text { the supply chain activities. }\end{array}$ \\
\hline
\end{tabular}

Our literature review reveals that the majority of the papers do not aim to build but rather to test theoretical concepts through the use of quantitative methods. These frameworks do not provide a clear understanding related to linkages between, and hierarchical relationships among constructs. Furthermore, the majority of the studies do not combine quantitative and qualitative methods (mixed-methods) to build theory, but use already existing theory to explain why particular phenomena take place and they do not build new theory. Furthermore, in cases where theory building is attempted, apart from a few exceptions, scholars do not use mixed methods. There is research where theoretical frameworks have been developed using Interpretive structural modeling (ISM) (i.e. Thakkar et al., 2008; Ali and Govindan, 2011; Luthra et al. 2011; Mathiyazhagan et al. 2013; Bag and Anand, 2014). However, even in these cases, scholars do not attempt to synthesize ISM model and MICMAC output and do not empirically test the proposed models. 
To resolve these limitations and show the use of mixed methods for theory building in the context of GSCM, we will use ISM to develop a theoretical framework where we will consult experts and try to explore possible linkages among each construct -enabler of GSCM (Table 1). ISM is a wellestablished methodology for identifying relationships among specific items/variables/factors that define a complex problem or an issue (e.g. Warfield, 1974; Sushil, 2012). It transforms poorly articulated complex models into visible and well-defined structural models showing the interrelationships between the variables (e.g. Ali et al. 2011; Attri et al. 2013). Lastly it is a modeling technique as it extrapolates the specific relationships between variables and overall structure in a particular form.

Scholars (e.g. Mandal and Deshmukh, 1994; Soti et al., 2009; Ali and Govindan, 2011; Sushil, 2012) have outlined two limitations of ISM, that is, it usually involves a small sample size which may not be enough for statistical reasons, and manager bias may influence the final ISM model. To deal with these limitations, we have further tested the ISM model using data collected through survey, and validate each construct of the model using confirmatory factor analyses (CFA) followed by regression analyses for hypothesis testing.

\section{Theoretical Framework and Research Hypothesis}

In this section we investigate the relationship between the enablers of GSCM that were extrapolated in Table 1 using ISM.

\subsection{Structural Self-Interaction Matrix}

Two groups of twenty-four participants in total, comprised of experts from industry and academia (twelve participants in each group), were consulted in identifying the nature of contextual relationship among the factors (Table 3).

They participated in two focus groups (academics and practitioners from industry) in order to discuss and identify the relationships between the factors. The authors of this paper facilitated the groups.

To analyze the variables (enablers of GSCM -Table 1), a contextual relationship of 'leads to' or 'influences' was chosen. On the basis of this, a contextual relationship between the identified variables is developed.

Table 3: Structural self-interaction matrix (SSIM)

\begin{tabular}{|c|c|c|c|c|c|c|c|c|c|}
\hline & IX & VIII & VII & VI & V & IV & III & II & I \\
\hline I (SRM) & V & V & V & A & V & A & A & O & \\
\hline
\end{tabular}




\begin{tabular}{|c|c|c|c|c|c|c|c|c|c|}
\hline II(CRM) & V & V & V & A & V & O & A & & \\
\hline III(TMC) & V & V & V & A & V & A & & & \\
\hline IV(IP) & $\mathrm{O}$ & $\mathrm{O}$ & $\mathrm{V}$ & $\mathrm{X}$ & $\mathrm{O}$ & & & & \\
\hline $\mathrm{V}(\mathrm{GTA})$ & $\mathrm{V}$ & $\mathrm{V}$ & $\mathrm{V}$ & $\mathrm{A}$ & & & & & \\
\hline $\mathrm{VI}(\mathrm{TQM})$ & $\mathrm{O}$ & $\mathrm{O}$ & $\mathrm{V}$ & & & & & & \\
\hline $\mathrm{VII(RCE)}$ & $\mathrm{O}$ & $\mathrm{V}$ & & & & & & & \\
\hline VIII(MS) & $\mathrm{O}$ & & & & & & & & \\
\hline IX(Profitability) & & & & & & & & & \\
\hline
\end{tabular}

Note: “i” denotes row and " $\mathrm{j}$ " denotes column

V - Antecedents $\mathrm{i}$ will help to achieve Antecedents j; A -

Antecedents $j$ will help to achieve Antecedents $i$;

$X$ - Antecedents $i$ and $j$ will help to achieve each other; and

$O$ - Antecedents $\mathrm{i}$ and $\mathrm{j}$ are unrelated

\subsection{Reachability Matrix}

The SSIM has been converted into a binary matrix i.e., the reachability matrix (Table 4) by substituting $V, A X$ and $O$ by 1 and 0 . For better understanding we have presented the guideline for translating $V, A, X$, and $O$ into binary digits as:

- If the $(i, j)$ entry in the SSIM is $V$, the $(i, j)$ entry in the reachability matrix becomes 1 and the $(j, i)$ entry becomes 0 ;

- If the $(i, j)$ entry in the SSIM is $A$, the $(i, j)$ entry in the reachability matrix becomes $O$ and the $(j, i)$ entry becomes 1 ;

- If the $(i, j)$ entry in the SSIM is $X$, the $(i, j)$ entry in the reachability matrix becomes 1 and the $(j, i)$ entry also becomes 1 ; and

- If the $(i, j)$ entry in the SSIM is $O$, the $(i, j)$ entry in the reachability matrix becomes 0 and the $(j, i)$ entry also becomes 0 .

After checking the transitivity property, the initial reachability matrix was translated into final reachability matrix as shown in Table 4. 
Table 4: Final Reachability Matrix

\begin{tabular}{|c|c|c|c|c|c|c|c|c|c|c|}
\hline & & & & & & & & & & $\begin{array}{c}\text { Driving } \\
\text { Power } \\
\text { (Y) }\end{array}$ \\
\hline I (SRM) & 1 & 0 & 0 & 0 & 1 & 0 & 1 & 1 & 1 & 5 \\
\hline II(CRM) & 0 & 1 & 0 & 0 & 1 & 0 & 1 & 1 & 1 & 5 \\
\hline III(TMC) & 1 & 1 & 1 & 0 & 1 & 0 & 1 & 1 & 1 & 7 \\
\hline IV(IP) & 1 & 0 & 1 & 1 & 0 & 1 & 1 & 0 & 0 & 5 \\
\hline V(GTA) & 0 & 0 & 0 & 0 & 1 & 0 & 1 & 1 & 1 & 4 \\
\hline VI(TQM) & 1 & 1 & 1 & 1 & 1 & 1 & 1 & 0 & 0 & 7 \\
\hline VII(RCE) & 0 & 0 & 0 & 0 & 0 & 0 & 1 & 1 & 0 & 2 \\
\hline VIII(MS) & 0 & 0 & 0 & 0 & 0 & 0 & 0 & 1 & 0 & 1 \\
\hline IX(Profitability) & 0 & 0 & 0 & 0 & 0 & 0 & 0 & 0 & 1 & 1 \\
\hline Dependence & & & & & & & & & & \\
Power (X) & 4 & 3 & 3 & 2 & 5 & 2 & 8 & 7 & 5 & \\
\hline
\end{tabular}

From the final reachability matrix, the reachability and antecedent set for each variable was found. The reachability set consists of the element itself and the other elements that it may help achieve, whereas the antecedent set consists of the element itself and the other elements that may help in achieving it. Further, the intersection of these sets was deduced for all the variables. The variables for which the reachability and the intersection sets are the same occupy the top level in the ISM hierarchy. The top-level element in the hierarchy would not help achieve any other element above its own level. Once the top-level element is identified, it is separated out from the other elements. Then, the same process is repeated to find out the elements in the next level.

This process is continued until the level of each element is found as shown in Table 5. These levels help in building the diagraph and the final model as shown in Figure 1. 


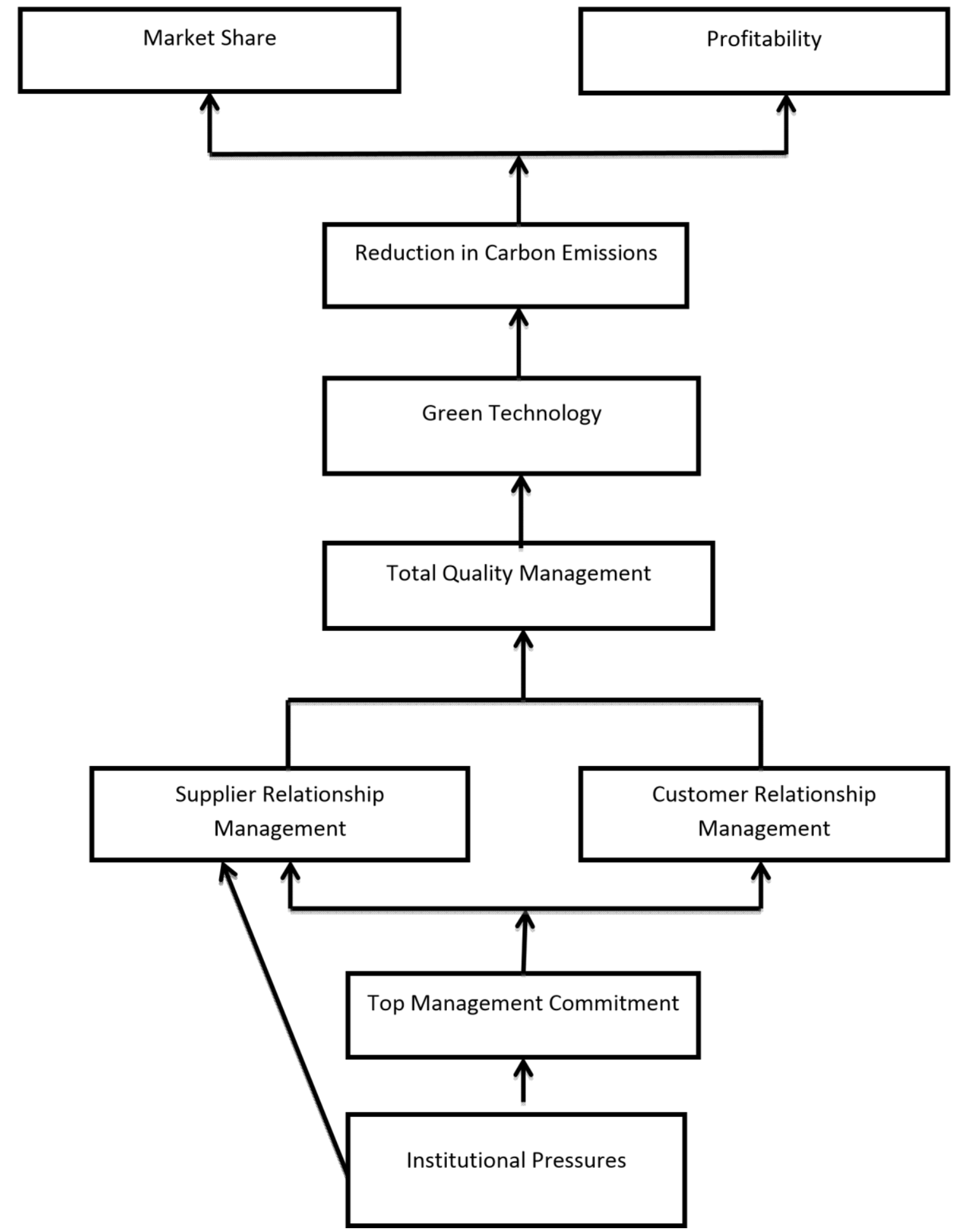

Figure 1: ISM Model Table 5: Levels of variables

\begin{tabular}{|c|c|}
\hline Variables & Level \\
\hline VIII,IX (MS, Profitability) & Level1 \\
\hline VII(RCE) & Level2 \\
\hline V(GTA) & Level3 \\
\hline
\end{tabular}




\begin{tabular}{|c|c|}
\hline $\mathrm{I}, \mathrm{II}(\mathrm{SRM}, \mathrm{CRM})$ & Level4 \\
\hline $\mathrm{III}(\mathrm{TMC})$ & Level5 \\
\hline $\mathrm{IV}(\mathrm{IP})$ & Level6 \\
\hline $\mathrm{VI}(\mathrm{TQM})$ & Level7 \\
\hline
\end{tabular}

\subsection{MICMAC analysis}

The objective of MICMAC analysis is to analyze the driving power and dependence of the variables. Based on the driving power and dependence of the factors have been classified into four clusters as:

Cluster 1: autonomous variables;

Cluster 2: dependence variables;

Cluster 3: linkage variables;

Cluster 4: driving variables

We have represented the position of each variable based on its dependence and driving power in the Table 6, which is shown graphically in Figure 2.

Table 6: Position coordinates of identified variables

\begin{tabular}{|c|c|}
\hline Variables & Position coordinates(X,Y) \\
\hline I (SRM) & $(4,5)$ \\
\hline II(CRM) & $(3,5)$ \\
\hline III(TMC) & $(3,7)$ \\
\hline IV(IP) & $(2,5)$ \\
\hline V(GTA) & $(5,5)$ \\
\hline VI(TQM) & $(2,7)$ \\
\hline VII(RCE) & $(8,2)$ \\
\hline VIII(MS) & $(7,1)$ \\
\hline
\end{tabular}




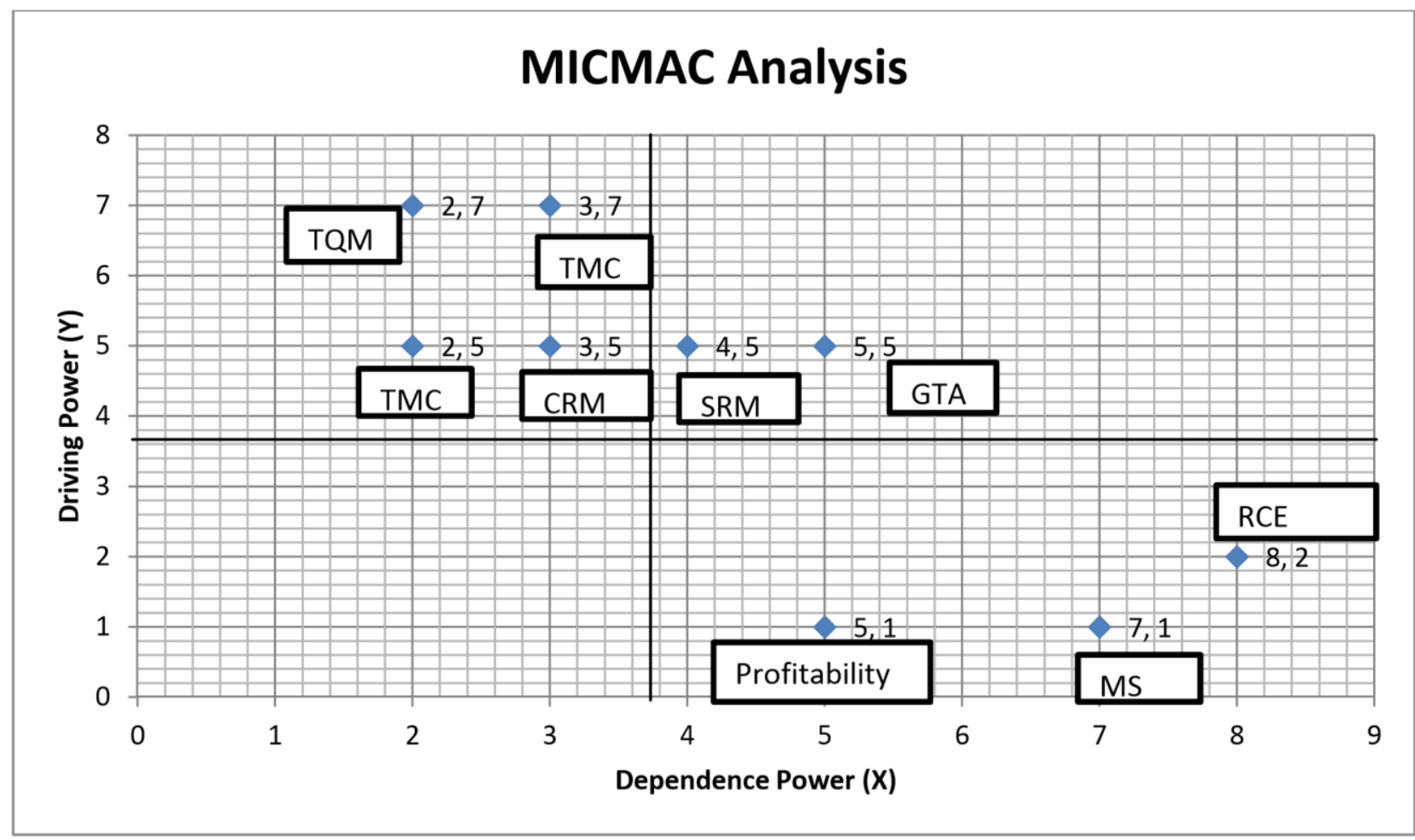

Figure 2: Driving power and dependence diagram

Cluster 1: Autonomous variables - These factors have a weak drive power and weak dependence. In this cluster we do not have any variables.

Cluster 2: Dependence variables - These factors have a weak drive power but strong dependence. In this cluster we have three variables, RCE, MS, and Profitability.

Cluster 3: Linkage variables - These factors have a strong drive power as well as strong dependence. In this cluster we have two variables, SRM and GTA.

Cluster 4: Driving variables - These factors have a strong drive power but weak dependence. In this cluster we have four variables, TQM, TMC, IP, and CRM).

Based on ISM and MICMAC analysis we propose our theoretical framework, which is outlined in the next section.

\subsection{Conceptual Framework}

In the previous section an ISM model was used to present the hierarchical relationships (among enablers) using a level matrix (see Table 5). The variables were further classified into four clusters 
based on dependence and driving power (see Figure 2). We attempted further to extend the existing literature by synthesizing the outcome of two independent analyses to build a conceptual framework. The conceptual framework depicts causality that was missing in the existing literature of ISM. The enablers (institutional pressures, top management commitment, customer relationship management, and total quality management) possess high driving power and low dependence power. Hence, we can consider these enablers as independent variables in our conceptual framework. The supplier relationship and green technology adoption have medium driving power and medium dependence power. Hence, we argue that these two building blocks will represent mediating variables of our conceptual framework and remaining enablers (environmental performance, market share, and increase in profit) have strong dependence power and weak driving power. Subsequently, we argue that these three enablers will be regarded as dependent variables of our conceptual framework. Here in our conceptual framework we have developed a single building block for market share and profitability of the organizations (see Figure 3). We have renamed it as financial performance. In this way we have derived a testable conceptual framework.

We argue that our present conceptual framework is grounded in three core principles (Melnyk et al., 2014). The first principle is identifying influencers. Our conceptual framework is an attempt to depict how institutional pressures are translated into desired managerial actions through human agents (top management). Here, two independent organizational theories, institutional theory (DiMaggio and Powell, 1981) and human agency theory (Eisenhardt, 1989) are integrated into a single conceptual framework.

The second principle states the design decision. Our conceptual framework is designed to achieve better environmental performance, achieve superior market share and improve profitability of the organizations. The third principle refers to the identification of building blocks. Here we have translated our enablers into building blocks that represent independent variables, mediating variables, and dependent variables (see Figure 3).

In the next section we test this framework deriving our research hypotheses from ISM and MICMAC output. 


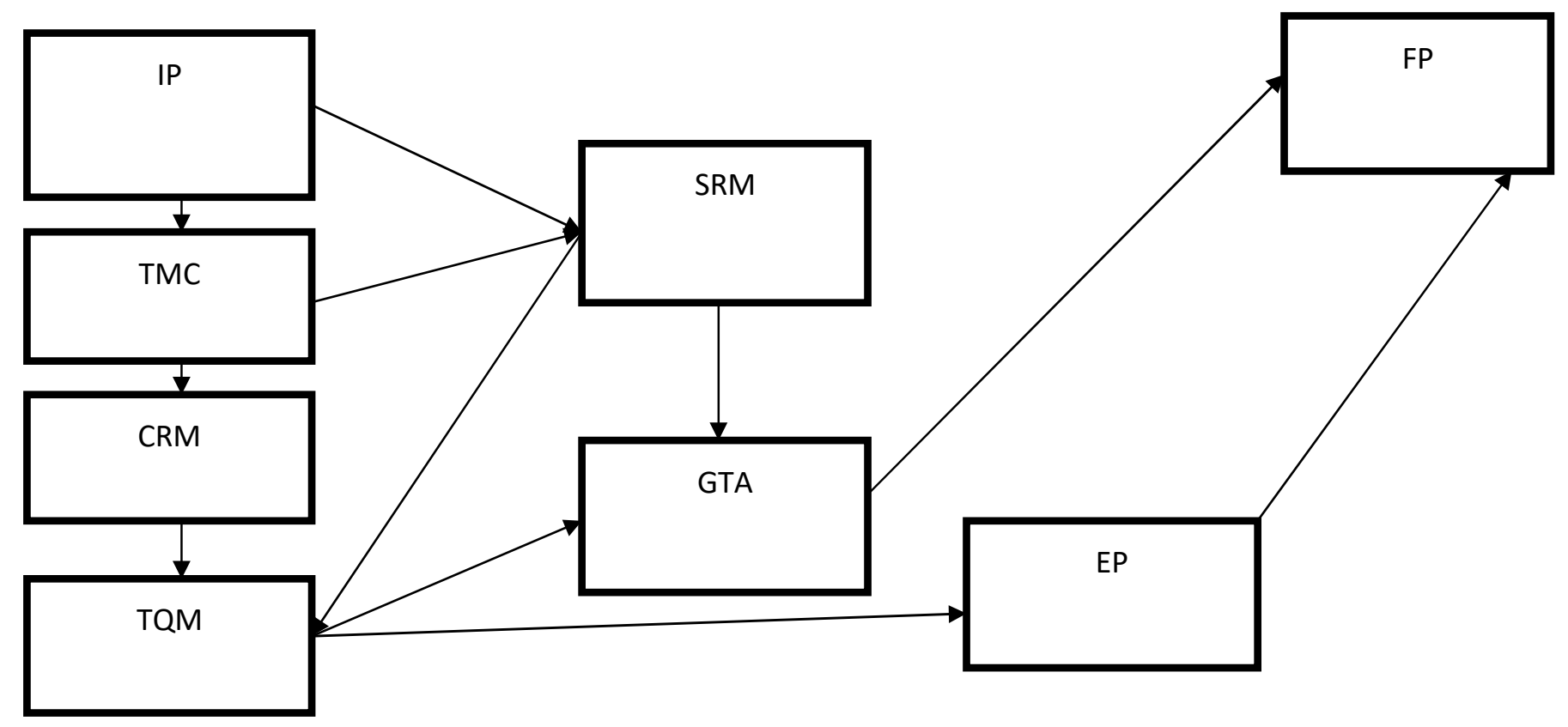

Figure 3: GSCM Framework

\subsection{Research hypotheses}

We have derived the research hypotheses shown in Table 7 from the proposed conceptual framework.

Table 7: Research Hypotheses

\begin{tabular}{|lr|l|}
\hline H1 (IP & TMC) & $\begin{array}{l}\text { There is a positive relationship between institutional pressures and top } \\
\text { management commitment }\end{array}$ \\
\hline H2 (TMC & CRM) & $\begin{array}{l}\text { There is a positive relationship between top management commitment and } \\
\text { customer relationship management }\end{array}$ \\
\hline H3 (CRM & TQM) & $\begin{array}{l}\text { There is a positive relationship between customer relationship management } \\
\text { and total quality management }\end{array}$ \\
\hline H4 (IP & SRM) & $\begin{array}{l}\text { There is a positive relationship between institutional pressures and supplier } \\
\text { relationship management }\end{array}$ \\
\hline H5 (TMC & SRM) & $\begin{array}{l}\text { There is a positive relationship between top management commitment and } \\
\text { supplier relationship management }\end{array}$ \\
\hline H6 (SRM & TQM) & $\begin{array}{l}\text { There is a positive relationship between supplier relationship management and } \\
\text { total quality management }\end{array}$ \\
\hline H7 (TQM & GTA) & $\begin{array}{l}\text { There is a positive relationship between total quality management and green } \\
\text { technology adoption }\end{array}$ \\
\hline H8 (TQM & EP) & $\begin{array}{l}\text { There is a positive relationship between total quality management and } \\
\text { environmental performance }\end{array}$ \\
\hline
\end{tabular}




\begin{tabular}{|ll|l|}
\hline H9 (GTA $\quad$ FP) & $\begin{array}{l}\text { There is a positive relationship between green technology adoption and } \\
\text { financial performance }\end{array}$ \\
\hline H10 (EP & FP) & $\begin{array}{l}\text { There is a positive relationship between environmental performance and } \\
\text { financial performance. }\end{array}$ \\
\hline
\end{tabular}

\section{Research design}

\subsection{Questionnaire design}

To develop the questionnaire, we began with a review of the extensive literature on the ten main concepts, as outlined in Table 1. We drew on our literature review but also on applications of Institutional Theory (DiMaggio and Powell, 1983) in the field of green supply chain management, where a number of researchers have used questionnaire surveys as instruments for empirical study. These included Flynn et al. (1994), Vachon and Klassen (2006), Zhu and Sarkis (2007), Hsu and $\mathrm{Hu}$ (2009), Bai and Sarkis (2010), Kauppi (2013), Kaynak (2003), Giovanni and Vinzi (2012), Zailani et al. (2012) and Yusuf et al. (2013). The questionnaire is consolidated into two sections:

- Section 1: questions on demographic profiles of the respondents like gender, age, designation, experience (years), type of product manufactured by their firm, size of the firm (number of people on payroll).

- Section 2: questions on top management commitment, regulatory pressures, market pressures, supplier relationship management, total quality management, green technology adoption, customer relationship management and environmental performance. Respondents were asked to rate on a five-point Likert scale (where 1 = Strongly Disagree, and 5 = Strongly Agree).

\subsection{Measures}

The measures were selected from the literature. We used multi-item measures of constructs for our proposed theoretical framework in order to improve reliability, reduce measurement error, ensure greater variability among survey individuals and improve validity (Churchill 1979). Each construct was operationalized using at least two items for measurement and analysed using confirmatory factor analysis (Hair et al. 1998; Anderson and Gerbing, 1988).

Institutional Pressures - We reviewed existing literature as a basis for developing this construct (Dimaggio and Powell, 1981; Zhu and Sarkis, 2007; Dubey et al. 2015). We have used four 
constructs from Zhu and Sarkis (2007) modified for the Indian manufacturing context (discussed in the next section).

Top management commitment - We have modified the items to measure TMC from existing literature (Hoof and Lyon 2013; Dubey et al. 2015). In our study we have used seven items (see Table 10).

Supplier relationship management - We have used five items that we have identified through extensive literature review. We modified the existing constructs (Testa and Iraldo 2010; Hoof and Lyon 2013; Dubey et al. 2015) as per Indian manufacturing firms context.

Customer relationship management - In our conceptual framework the customer relationship management is one of the independent variables. To measure the CRM construct we have undertaken extensive literature review. We have used three items which we have derived from existing literature (Seuring et al. 2004; Zhu et al. 2008; Baines et al. 2012).

Total quality management - In our study we have used three items construct. We have modified the existing constructs (Kaynak, 2003; Dubey et al. 2015) as per our requirements.

Green technology adoption - As we have discussed in our preceding section, green technology is an important enabler. In our conceptual framework GTA is acting as a mediating variable between independent and dependent variables.

In our study we have used seven items construct, which we have derived from existing literature (Nguene et al. 2011; Zhang et al. 2013; Hoof and Lyon 2013).

Firm Performance - We have used two-item construct. The items are derived using existing literature (Dues et al. 2013; Gavronski et al. 2011).

Environmental Performance - Environmental performance is an important outcome of any green supply chain network design. In our present study we have used six items construct. The items were derived from existing literature (Zhu and Sarkis, 2004; Wagner and Schaltegger, 2004; Schoenherr, 2012; Zhang and Wang, 2014; Dubey et al. 2015).

The items included in the final questionnaire were pre-tested with 24 experts drawn from industry and academia to check the content validity. We have incorporated all the suggestions of the experts. The suggestions were mainly related to the wording of the questionnaire and some items regarding relationships with partners. We did not disclose constructs to the respondents to eliminate respondent bias, as we will discuss in the data collection section. 


\subsection{Sampling}

We have targeted manufacturing firms situated in West Bengal, Pune, Maharashtra, Tamil Nadu, NCR and Gujarat regions which are regarded as manufacturing hubs of India. The Indian manufacturing sector at present contributes nearly 15\% of the total GDP of India (CII-BCG Report, 2012). Although we do not have any concrete statistics, the manufacturing sector mainly steel, cement, chemical, rubber and other allied sectors are regarded as major contributors to environmental pollution. For our study we took data on the firms from the Confederation of Indian Industries (CII) database.

\subsection{Data collection}

We collected data electronically using the split-survey method (Podsakoff et al.

2003). The questionnaire was divided into two parts. The first part contained questions related to top management commitment, customer relationship, regulatory pressures, market pressures, supplier relationship management, total quality management, profitability and market share. The second part of the questionnaire consisted of environmental related variables. The survey was sent to targeted individuals in procurement departments in the Indian manufacturing sector to respond to questions related to their relationships with partners. These individuals were requested to pass on the remaining questions to their colleagues from quality, human resource departments, marketing department and finance department to complete the questions related to their competencies. The second part of the questionnaire was sent to environmental managers of the same firms, as they are more knowledgeable about questions related to environmental performance. The split survey method allowed us to address the most informed respondents to answer our questions. Prior to questioning, respondents were assured that responses would not be revealed.

Our initial survey frame consisted of 742 firms situated throughout India and was compiled from a database provide by Cll. This database was chosen to reach a high number of executives of sufficient seniority and knowledge to answer the split survey. Data collection was conducted using a modified version of Dillman's (2007) total design method. Overall, we received 343 complete and usable responses for the first part and 174 complete and usable responses for the second part. The firm response rate is therefore $343 / 742=46.22 \%$ and the split survey ratio is $174 / 343=50.72 \%$. Here, the response ratio as well as split ratio were both decent in comparison to other research in the past. The sample size is sufficient enough to test the research hypotheses developed in this study (Hair et al. 1998), and is comparable to the response rate achieved in other recent research investigating supply chain and operations management topics. As the 
questionnaire was part of a larger research project that ran to 6 pages in total, this may explain the belowaverage response rate. During our follow up with respondents who were senior managers, they revealed that they are quite reluctant to engage in external surveys. They revealed that in recent years, companies in India have formulated policies not to respond to any external survey that is not routed through proper channels. Overall, 48.69 per cent of the total respondents belonged to top management, 39.65 per cent to middle management and 11.66 per cent represents young managers. The profiles of the respondents are shown in Table 8 and the response collected from respondents is shown in Table 9 to check the non-response bias of the collected responses. 
Table 8: Respondents Profile

\begin{tabular}{|c|c|c|c|}
\hline \multicolumn{2}{|c|}{ Demographic Profile } & \multirow{2}{*}{$\begin{array}{l}\text { Number of } \\
\text { respondents } \\
45\end{array}$} & \multirow{2}{*}{$\begin{array}{l}\text { Percentage of respondents } \\
13.12\end{array}$} \\
\hline \multirow{4}{*}{ Job Title } & Vice President & & \\
\hline & General Managers & 122 & 35.57 \\
\hline & Managers & 136 & 39.65 \\
\hline & $\begin{array}{l}\text { Deputy/Assistant } \\
\text { Managers }\end{array}$ & 40 & 11.66 \\
\hline \multirow{5}{*}{$\begin{array}{l}\text { Work experience } \\
\text { (years) }\end{array}$} & Above 20 & 166 & 48.40 \\
\hline & $15-20$ & 77 & 22.45 \\
\hline & $14-10$ & 78 & 22.74 \\
\hline & $9-5$ & 12 & 3.50 \\
\hline & $0-4$ & 10 & 2.92 \\
\hline \multirow{5}{*}{ Age of the firms } & $>20$ & 110 & 32.07 \\
\hline & $15-20$ & 200 & 58.31 \\
\hline & $14-10$ & 33 & 9.62 \\
\hline & $9-5$ & 0 & 0.00 \\
\hline & $4-0$ & 0 & 0.00 \\
\hline \multirow{5}{*}{ Revenue } & $>2000$ crores (INR) & 75 & 21.87 \\
\hline & $\begin{array}{l}\text { 1500-2000 crores } \\
\text { (INR) }\end{array}$ & 150 & 43.73 \\
\hline & $\begin{array}{l}\text { 1000-1499 crores } \\
\text { (INR) }\end{array}$ & 75 & 21.87 \\
\hline & $500-999$ crores (INR) & 10 & 2.92 \\
\hline & $<500$ & 33 & 9.62 \\
\hline \multirow{5}{*}{ Number of employees } & Greater than 500 & 200 & 58.31 \\
\hline & $250-500$ & 120 & 34.99 \\
\hline & $100-249$ & 23 & 6.71 \\
\hline & Less than 100 & & 0.00 \\
\hline & Less than 100 & & 0.00 \\
\hline
\end{tabular}




\subsection{Non-response bias}

Following other studies (e.g. Armstrong and Overton 1977; Lambert and Harrington 1990; Chen and Paulraj 2004), the final sample was ranked according to the date each response was received and split into equally sized groups. We compared the first 100 respondents (early-wave group) against the last 100 respondents. Comparison analysis was based on all variables: t-tests performed on the two groups yielded no statistically significant differences (at 95\% confidence interval). Hence, we concluded that non-response bias is not a major issue.

Table 9: Response collected using questionnaire

\begin{tabular}{|c|c|c|c|}
\hline & & 1st Wave & 2nd Wave \\
\hline Industry & Targeted & Response & Response \\
\hline Automotive & 180 & 24 & 12 \\
\hline Machinery & 54 & 23 & 13 \\
\hline Electrical Goods Manufacturing & 57 & 15 & 10 \\
\hline Wood \& Wood Products & 58 & 10 & 8 \\
\hline Pharma & 42 & 7 & 10 \\
\hline Food Products & 20 & 6 & 7 \\
\hline Plastic Products & 45 & 15 & 10 \\
\hline Rubber & 80 & 25 & 27 \\
\hline Steel Units & 60 & 10 & 20 \\
\hline $\begin{array}{l}\text { Graphite Electrodes \& } \\
\text { Lubricants }\end{array}$ & 30 & 15 & 10 \\
\hline Cement & 50 & 7 & 13 \\
\hline Textile Product & 15 & 5 & 6 \\
\hline Optical Instruments & 6 & 2 & 2 \\
\hline Basic Metals and Fabricated & 20 & 10 & 7 \\
\hline Electronics Industry & 25 & 6 & 8 \\
\hline & 742 & 180 & 163 \\
\hline
\end{tabular}

\section{Data analysis}

\subsection{Assessment of Psychometric properties}


Before evaluating the reliability and validity of the measurement items, the constructs were tested for the assumption of constant variance, existence of outliers, and normality. We used residual plots and statistics of skewness and kurtosis. The maximum absolute values of the skewness and kurtosis of the items were found to be 1.496 and 1.169 , respectively. These values are well within the limits recommended by past research (univariate skewness $<2$, kurtosis $<7$ ) (Curran et al. 1996). Neither the plots nor the statistics indicated any significant deviances from assumptions.

After we had checked the assumptions, we used CFA to establish convergent validity and discriminant validity (Fornell and Larcker 1981). Table 10 provides values of standardized factor loadings $(\lambda)$, scale composite reliability (SCR) and average variance extracted (AVE).

Table 10: Reliability test, scale composite reliability (SCR) and average variance extracted (AVE)

\begin{tabular}{|c|c|c|c|c|}
\hline Scale & Items & $\mathrm{i}$ & SCR & AVE \\
\hline \multirow{7}{*}{$\begin{array}{c}\text { Top Management } \\
\text { Commitment } \\
\text { Cronbach's Alpha: } \\
0.947\end{array}$} & Our company has a well-defined environmental policy. & 0.93 & 0.96 & 0.77 \\
\hline & $\begin{array}{l}\text { Every employee is aware about the firm's environmental } \\
\text { policy. }\end{array}$ & 0.90 & & \\
\hline & $\begin{array}{l}\text { Top management supports environmental } \\
\text { programs. }\end{array}$ & 0.85 & & \\
\hline & $\begin{array}{l}\text { Top management has approved a special fund for investment } \\
\text { in cleaner technologies. }\end{array}$ & 0.88 & & \\
\hline & $\begin{array}{l}\text { Senior managers show a positive attitude towards green } \\
\text { practices. }\end{array}$ & 0.84 & & \\
\hline & $\begin{array}{l}\text { Senior managers motivate and support new ideas received } \\
\text { from junior executives. }\end{array}$ & 0.86 & & \\
\hline & $\begin{array}{l}\text { Employees are recognized for innovative ideas and rewarded } \\
\text { on a periodic basis. }\end{array}$ & 0.87 & & \\
\hline
\end{tabular}

\begin{tabular}{|c|c|c|c|c|}
\hline \multirow{4}{*}{$\begin{array}{c}\text { Institutional } \\
\text { Pressures } \\
\text { Cronbach's Alpha: } \\
0.885\end{array}$} & $\begin{array}{l}\text { Regional pollution control board is pressurizing the firm to } \\
\text { adopt green practices. }\end{array}$ & 0.91 & 0.92 & 0.74 \\
\hline & $\begin{array}{l}\text { Government regulations provide clear guidelines in } \\
\text { controlling pollution level. }\end{array}$ & 0.83 & & \\
\hline & $\begin{array}{l}\text { The customers are sensitive towards environmental friendly } \\
\text { manufacturing practices. }\end{array}$ & 0.89 & & \\
\hline & $\begin{array}{l}\text { Green practices decrease incidences of penalty fee charged } \\
\text { by pollution control board. }\end{array}$ & 0.83 & & \\
\hline \multirow{2}{*}{$\begin{array}{c}\text { Supplier } \\
\text { Relationship } \\
\text { Management } \\
\text { Cronbach's Alpha: }\end{array}$} & $\begin{array}{l}\text { Environmental criteria are considered while selecting } \\
\text { suppliers. }\end{array}$ & 0.90 & 0.97 & 0.86 \\
\hline & Our firm considers environment collaboration with suppliers. & 0.95 & & \\
\hline
\end{tabular}




\begin{tabular}{|c|c|c|c|c|}
\hline \multirow{4}{*}{0.960} & \multirow[b]{2}{*}{ Our firm has technological integration with suppliers. } & \\
\hline & & 0.90 & & \\
\hline & $\begin{array}{l}\text { Our firm trains and educates suppliers in implementing ISO } \\
14001 .\end{array}$ & 0.95 & & \\
\hline & $\begin{array}{l}\text { Our firm conducts environmental audit for suppliers at } \\
\text { regular interval. }\end{array}$ & 0.95 & & \\
\hline \multirow{3}{*}{$\begin{array}{c}\text { Total Quality } \\
\text { Management } \\
\text { Cronbach's Alpha: } \\
0.715\end{array}$} & Total quality management philosophy helps to reduce waste. & 0.91 & 0.86 & 0.82 \\
\hline & The raw materials used cause less environmental damage. & 0.90 & & \\
\hline & Green practices promote product quality. & 0.91 & & \\
\hline \multirow{7}{*}{$\begin{array}{c}\text { Green Technology } \\
\text { Adoption Cronbach's } \\
\text { Alpha: } \\
0.926\end{array}$} & Our firm is focusing on green design of products. & 0.92 & 0.941 & 0.72 \\
\hline & The green design reduces wastage. & 0.88 & & \\
\hline & $\begin{array}{l}\text { Real time information is available any point of time by using } \\
\text { Information technology infrastructure SAP/ERP. }\end{array}$ & 0.91 & & \\
\hline & Our firm focuses on using alternate source of energy & 0.87 & & \\
\hline & Our firm has optimized process to reduce wastage & 0.56 & & \\
\hline & Our firm is using eco-friendly materials for packaging & 0.87 & & \\
\hline & $\begin{array}{l}\text { Reduction of emission of Green House Gases in the } \\
\text { environment by use of clean technology }\end{array}$ & 0.86 & & \\
\hline \multirow{2}{*}{$\begin{array}{c}\text { Financial Performance } \\
\text { Cronbach's Alpha: } \\
0.981\end{array}$} & Green practices improve a firm's profit. & 0.73 & 0.78 & 0.64 \\
\hline & Green practices improve a firm's market share. & 0.87 & & \\
\hline \multirow{6}{*}{$\begin{array}{c}\text { Environmental } \\
\text { Performance } \\
\text { Cronbach's Alpha: } \\
0.881\end{array}$} & Green practices reduce solid waste generation. & 0.88 & 0.92 & 0.65 \\
\hline & $\begin{array}{l}\text { Effluent meets CPCB norms by converting into green } \\
\text { operations }\end{array}$ & 0.82 & & \\
\hline & $\begin{array}{l}\text { Green practices reduce environmental accidents and health } \\
\text { hazards. }\end{array}$ & 0.88 & & \\
\hline & Green practices decrease of cost of raw materials. & 0.54 & & \\
\hline & Green practices reduce the inventory levels. & 0.86 & & \\
\hline & $\begin{array}{l}\text { Green practices } \\
\text { consumption. }\end{array}$ & 0.80 & & \\
\hline \multirow{3}{*}{$\begin{array}{c}\text { Customer } \\
\text { Relationship } \\
\text { Management } \\
\text { Cronbach's Alpha: } \\
0.787\end{array}$} & Green practices improve customer satisfaction. & 0.82 & 0.88 & 0.71 \\
\hline & Customers' feedback is used in product design. & 0.84 & & \\
\hline & Customers appreciate eco-friendly products. & 0.87 & & \\
\hline
\end{tabular}


In Table 10 it is suggested that standardized factor loadings of indicators, SCR and AVE are well above the specified lower values (i.e. $\lambda_{i}$ should be ideally greater than 0.7 and must be $\geq 0.5, S C R$ $\geq 0.7$ and $A V E \geq 0.5$ ). We can therefore conclude that constructs of our theoretical framework possess convergent validity. To determine discriminant validity, we have derived the inter-factors correlation matrix and modified it as per the suggestions by Fornell and Larcker (1981), as shown in Table 11.

Table 11: Discriminant Validity

\begin{tabular}{|l|c|r|r|r|r|r|r|l|}
\hline & & & & & & & & \\
& TMC & IP & CRM & SRM & TQM & GTA & FP & EP \\
\hline TMC & $0.88^{*}$ & & & & & & & \\
\hline IP & $0.44^{* *}$ & $0.86^{*}$ & & & & & & \\
\hline SRM & $0.48^{* *}$ & $0.19^{* *}$ & $0.93^{*}$ & & & & & \\
\hline TQM & $0.39^{* *}$ & $0.32^{* *}$ & $0.61^{* *}$ & $0.90^{*}$ & & & & \\
\hline TQM & $0.47^{* *}$ & $0.64^{* *}$ & $0.52^{* *}$ & $0.32^{* *}$ & $0.90^{*}$ & & & \\
\hline GTA & $0.26^{* *}$ & $0.38^{* *}$ & $0.31^{* *}$ & $0.31^{* *}$ & $0.41^{* *}$ & $0.85^{*}$ & & \\
\hline FP & $0.31^{* *}$ & $0.48^{* *}$ & $0.21^{* *}$ & $0.30^{* *}$ & $0.43^{* *}$ & $0.53^{* *}$ & $0.81^{*}$ & \\
\hline CRM & $0.42^{* *}$ & $0.23^{* *}$ & $0.17^{* *}$ & $0.37^{* *}$ & $0.46^{* *}$ & $0.47^{* *}$ & $0.39^{* *}$ & $0.93^{*}$ \\
\hline
\end{tabular}

From Table 11, we can see that the absolute values for entries marked $\left({ }^{* *}\right.$ ) (correlation coefficient) are lower than the absolute value of square root of AVE entries $\left({ }^{*}\right)$. This suggests that the constructs possess discriminant validity (Fornell and Larcker 1981). We have also estimated the fit indices for the overall measurement model; Normed Chi-Square=0.31, which suggests that $x^{\wedge} 2 / d f \leq 2$, represent a better fit (Hu and Bentler 1999). RMSEA was found to be 
0.07 which suggests that model is a better fit.

\subsection{Hypothesis tests}

We have tested our hypotheses, which represent the links of the framework using regression analysis. The regression analysis outputs are presented in Table 12.

Table 12: Regression Analysis Output

\begin{tabular}{|c|c|c|c|c|c|c|c|}
\hline Hypotheses & $\mathrm{R}$ & $\mathrm{R}^{\wedge} 2$ & $F(d f 1, d f 2)$ & ß & pvalue & $\begin{array}{l}\text { Durbin- } \\
\text { Watson } \\
\text { statistic }\end{array}$ & $\begin{array}{l}\text { Hypotheses } \\
\text { supported } \\
\text { or not- } \\
\text { supported }\end{array}$ \\
\hline $\mathrm{H} 1$ & 0.728 & 0.527 & 193.862 & 0.574 & 0.000 & 1.649 & supported \\
\hline $\mathrm{H} 2$ & 0.886 & 0.786 & 630.032 & 1.017 & 0.000 & 1.698 & supported \\
\hline H3 & 0.901 & 0.812 & 741.767 & 0.852 & 0.000 & 1.874 & supported \\
\hline $\mathrm{H} 4$ & 0.731 & 0.534 & 196.874 & 1.082 & 0.000 & 1.776 & supported \\
\hline H5 & 0.829 & 0.687 & 377.851 & 0.968 & 0.000 & 1.513 & supported \\
\hline H6 & 0.813 & 0.660 & 334.594 & 0.755 & 0.000 & 1.911 & supported \\
\hline $\mathrm{H} 7$ & 0.910 & 0.829 & 832.642 & 0.821 & 0.000 & 1.602 & supported \\
\hline H8 & 0.794 & 0.630 & 293.383 & 0.537 & 0.000 & 1.745 & supported \\
\hline H9 & 0.680 & 0.462 & 147.808 & 0.609 & 0.000 & 1.643 & Supported \\
\hline H10 & 0.809 & 0.654 & 325.295 & 0.783 & 0.000 & 1.626 & Supported \\
\hline
\end{tabular}

From Table 12, we can conclude that all stated hypotheses are supported. It can be clearly seen that the $R^{\wedge} 2$ value of each linkage is quite high and the beta coefficients of each path of Figure 5 are found to be positive and statistically significant at $p=0.000$. The Durbin-Watson statistics of each model are found to be between 0 and 4 (Mooi and Sarstedt, 2011, p.174). 
In our case we can see that the Durbin-Watson statistics are well within range, suggesting no auto correlation effect. The Fcr $(1,344)$, for each linkage is 3.84. In our case we found the value of Fstatistic is well above 3.84 for each linkage. Overall we can conclude that the constructs and the measures of the theoretical model, derived using the ISM technique \& MICMAC analysis based on experts' opinions, are found to be valid and each linkage was supported and found to be statistically significant.

\subsection{Discussion}

In this paper we set off to argue for the use of mixed methods in order to build theory within OM and SCM research, with a particular focus on GSCM. Research in logistics and SCM has been heavily criticized in that scholars do not engage in methodological diversity and they are unwilling to adopt additional methods that might be more appropriate for the research question at hand (Golicic and Davis, 2012). Scholars so far have been using either quantitative methods (surveys, experiments) (Boyer and Swink, 2008) or qualitative research (Voss et al., 2002; Barratt et al., 2011; Manuj and Pohlen, 2012); mixing methods has been rare. We realized after a comprehensive literature review, that there are limited studies focusing on using mixed methods for theory building. The study by Golicic and Davis (2012) does argue for the use of mixed methods in SCM, but it does not focus on using mixed methods, but only on designing and reporting such studies. Therefore, driven by the endorsement of scholars to build methodological approaches and techniques that pay attention to the dynamic environment of OM and SCM, and in our case GSCM, we argue and illustrate the use of mixed methods for GSCM for theory building. Using three important components of 'unique contributions' i.e. What, How and Why? (Whetten, 1989), we have attempted to answer three vital questions in terms of variables which we have identified from the synthesis of literature on the enablers of GSCM, as well as from the opinion of experts. We have developed contextual relationships between GSCM enablers using the ISM approach and further refined them using MICMAC analysis. A model has been developed that was further tested using CFA. In this way, we have integrated two diverse techniques, to draw deeper insight into existing GSCM practices.

Our hypotheses were all supported; in particular our study highlights the importance of institutional pressures (Ketokivi and Schroeder, 2004; Ketchen and Hult, 2007; Liu et al., 2010; Sarkis et al., 2011; Bhakoo and Choi, 2013; Kauppi, 2013; Dubey et al. 2014) and top management commitment (Liang et al., 2007; Gattiker and Carter, 2010; Foerstl et al., 2015; Jabbour and Jabbour, 2015) in the management of both suppliers and customers within the context of GSCM. Firms that engage in establishing strong relationships with suppliers enjoy superior performance 
(Giannakis, 2007; Reuter et al., 2010; Gimenez and Tachizawa, 2012; Burritt and Schaltegger, 2012). In our study, we did not show that CRM and SRM are directly influencing performance (either environmental or financial) but that they enable GTA and TQM and then influence environmental and financial performance. Furthermore, we extended those studies illustrating the role of TMC in mediating the relationships between institutional pressures and intention to adopt best sustainability practices, in that we showed that TMC mediates the relationship between institutional pressures (either external or internal) and customer relationship management. Hence TMC may 'translate' different pressures into initiatives with target particular customers and aim to maintain relationship with them. In this vein, our study highlights the role of developing appropriate strategies that translate pressures into management and foster collaboration with suppliers and customers (Hsu and Hu, 2009; Ku et al., 2010; Hoejmose et al., 2012; Shaw et al., 2012; Caniels et al., 2013; Govindan et al., 2013; Zhu et al., 2013).

\section{Conclusion}

In this study we argued for the use of mixed method research for theory building in GSCM research, driven by the dearth of literature in building robust methodological approaches and techniques that take into account the dynamic nature of green supply chains. We undertook an extensive literature review and identified enablers of GSCM practices, which were then further discussed by experts. We understood the relationship of these factors through ISM and MICMAC analysis, and based on the results we further developed a conceptual framework. This framework was tested and validated using CFA; all our hypotheses were supported. Our contribution lies in moving beyond designing or presenting mixed methods' SCM research for SCM, but offering an illustration of how mixed methods can contribute to the development of new theory (via the presentation and validation of a framework on enablers of GSCM). Furthermore, we contribute to the literature exploring the role of IP and TMC in environmental and financial performance in that we show that TMC translates external and internal pressures (described by IP) into SRM and CRM and GTA, and subsequently financial performance. Environmental performance relates to SRM since the latter enables the adoption of TQM that influences environmental performance.

Our results also provide useful lessons for practice in that they suggest that the manufacturing companies that adopt GSCM, believe in collaborative practices, and involve their suppliers in their strategy enjoy superior advantage in terms of positive business performance and environmental performance. Furthermore, they highlight the role of SRM and CRM as drivers of GSCM practices in the Indian and hence developing countries' context. Today environmental concerns have triggered the need for adopting green supply chain practices. Customers recognize the need for 
sustainability practices; however the only question that comes to mind is whether customers are willing to pay. Our findings imply that companies should not consider only this question, but engage in strategies that will enable them to achieve superior environmental and financial performance; our findings suggest that there is a positive relationship between environmental and financial performance.

The identified factors may not cover all the aspects of GSCM. The present study clearly highlights that Indian manufacturing firms have slowly realized the importance of GSCM practices. In India, GSCM practices are starting out with a long way to travel. However some interesting and encouraging findings may motivate researchers to offer some insights that can certainly benefit those manufacturing companies who are willing to adopt GSCM practices. It should be noted that our findings are based on those organizations that have invested significant resources in implementation of GSCM practices within Indian rubber goods manufacturing companies. The present study has attempted to identify the enablers of GSCM and their relationship. The present study could have been benefited if we would have also studied the barriers that impede the adoption of GSCM in those organizations that are still in the implementation phase or at the process of deciding whether or not they will embrace GSCM practices. However, the value of this study lies also in providing useful insights on the enablers of GSCM for emerging economies since, as in other studies within emerging economies (Zhu et al., 2008), Indian organizations are not yet mature and do not possess the necessary knowledge and resources in order to embrace GSCM, compared to emergent economies (Hsu et al., 2013).

Our research has limitations. Firstly, the study uses data that have been collected in India from manufacturing firms. Secondly, top management commitment has been studied and measured based on the literature and a single combined construct. However, top management beliefs and top management participation as two constructs could have been instead studied to provide more precise insights into top management commitment. Finally, we have no assumed some key aspects like product complexity and environmental uncertainty (i.e. supply uncertainty, demand uncertainty and technological uncertainty) as moderating and controllable behaviors to draw better insights.

Notwithstanding the limitations, we have identified some future research directions:

i. The study illustrated the use of mixed methods for theory building in GSCM using ISM and MICMAC analyses, as well as CFA. The selection of these methods was based on their ability to discover and validate relationships between our enablers. Depending on the research question(s), other methods or their combination may also be used. Hudson and Ozanne (1988) suggest that although research paradigm incommensurability exists, it 
does not imply that "the two approaches cannot peacefully coexist or that other middleground approaches cannot or should not be developed" (p. 508).

ii. Our research can further be enhanced using multiple cases in both developing and developed countries. Such research could qualitatively validate our proposed model before we validate it using quantitative methods.

iii. In this research we used focus groups with participants from industry and academia. However, other methods could be used, e.g. Delphi methods.

iv. The present study has not included top management beliefs and top management participation as two different constructs. In future, it may be fruitful to include these two constructs to draw further insights on GSCM practices.

v. The present study can also be extended to the service sector of developing countries. In India, the service sector is the fastest growing industry and useful results for further development of the sector can be derived from such a study.

vi. This study on the barriers of GSCM implementation can be further extended to include developing countries. In this vein a comparison between developed and developing countries could take place, with the aim to inform the literature on the similarities and differences, but also lessons for the practical application and achievement of GSCM.

We believe that our study provides food for thought for those who would like to further engage into mixed method research for theory building in GSCM, and study the enablers of GSCM.

\section{Acknowledgements}

The authors are most grateful to two anonymous reviewers and the Guest Editor of the special issue, Professor Charbel Jabbour for their extremely constructive and helpful comments on the earlier version of the manuscript which helped to improve the presentation of the paper considerably.

\section{References}

Abdulrahman, M. D., Gunasekaran, A., and Subramanian, N. (2014). Critical barriers in implementing reverse logistics in the Chinese manufacturing sectors. International Journal of Production Economics 147, 460-471.

Ahi, P., \& Searcy, C. (2013). A comparative literature analysis of definitions for green and sustainable supply chain management. Journal of Cleaner Production, 52, 329-341.

Akman, I., and Mishra, A. (2015). Sector diversity in Green Information Technology practices: Technology Acceptance Model perspective. Computers in human behavior 49, 477-486. 
Aldag, R.J., and Steams, T.M. (1988). Issues in research methodology. Journal of Management 14(2), 253-276.

Ali, D., and Govindan, K. 2011. An analysis of the drivers affecting the implementation of green supply chain management. Resources, Conservation and Recycling 55(6), 659-667.

Anderson, J.C., and Gerbing, D.W. (1988). Structural Equation Modeling in Practice: A Review and Recommended Two-Step Approach. Psychological Bulletin 103 (May), 411-423.

Armstrong, J.S., and Overton, T.S. Estimating Non-response Bias in Mail Surveys. Journal of Marketing Research 14 (3), 396-402.

Attri, R., Dev, N., and Sharma, V. (2013). Interpretive Structural Modeling (ISM) approach: An overview. Research Journal of Management Sciences 2(2), 3-8

Awaysheh, A., and Klassen, R. (2010). The impact of supply chain structure on the use of supplier socially responsible practices", International Journal of Operations \& Production Management 30(12), 1246-1268.

Bag, S., \& Anand, N. (2014). Modeling Green Supply Chain Management framework using ISM and MICMAC analysis. African Journal of Business Management, 8(22), 1053-1065.

Bai, C., and Sarkis, J. (2010). Greener Supplier Development: Analytical Evaluation Using Rough Set Theory. Journal of Cleaner Production 17(2), 255-264.

Baines, T., Brown, S., Benedettini, O., and Ball, P. (2012). Examining Green Production and its Role within the Competitive Strategy of Manufacturers.

Journal of Industrial Engineering and Management 15 (1), 53-87.

Bell, J. E., Autry, C. W., Mollenkopf, D. A., \& Thornton, L. M. (2012). A natural resource scarcity typology: theoretical foundations and strategic implications for supply chain management. Journal of Business Logistics, 33(2), 158-166.

Berkel, V. (2007). Cleaner Production and Eco-efficiency in Australian Small

Firms. International Journal of Environmental Technology and Management 7 (5/6), 672693.

Bhakoo, V., and Choi, T. (2013). The iron cage exposed: Institutional pressures and heterogeneity across the healthcare supply chain. Journal of Operations Management 31(6), 432 - 449.

Bierma, T.J., and Wasterstraat, F.L. (1999). Cleaner Production from Chemical Suppliers: Understanding Shared Savings Contracts. Journal of Cleaner Production 7(2), 145-158.

Binder, M., Edwards, J.S. (2010). Using grounded theory method for theory building in operations management research. International Journal of Operations \& Production Management 30(3), 232-259.

Bitektine, A., (2008). Prospective case study design qualitative method for deductive theory testing. Organizational Research Methods 11(1), 160-180.

Brockhaus, S., Kersten, W., \& Knemeyer, A. M. (2013). Where do we go from here? Progressing sustainability implementation efforts across supply chains. Journal of Business Logistics, 34(2), 167-182. 
Burgess, K., Singh, P.K., and Koroglu, R. (2006). Supply chain management: a structured literature review and implications for future research.

International Journal of Operations and Production Management 26(7), 703729.

Burritt, R., and Schaltegger, S. (2012). Measuring the (Un-)Sustainability of Industrial Biomass Production and Use. Sustainability Accounting, Management and Policy Journal 3(2), 109-133.

Buyukozkan, G., and Cidci, G., (2012). A novel hybrid MCDM approach based on fuzzy DEMATEL, fuzzy ANP and fuzzy TOPSIS to evaluate green suppliers. Expert Systems with Applications 39(3), 3000-3011.

Caniels, M.C., Gehrsitz, M.H. and Semeijn, J. (2013). Participation of suppliers in greening supply chains: An empirical analysis of German automotive suppliers. Journal of Purchasing \& Supply Management 19(3), 134-143.

Chaabane, A., Ramudhin, A., and Paquet, M. (2012). Design of Sustainable Supply Chains under Emission Trading Scheme. International Journal of Production Economics 135(1), 37-49.

Chen, D.Q., Mocker, M., Preston, D.S., and Teubner, A. (2010). Information systems strategy: reconceptualisation, measurement, and implications. MIS Quarterly 34(2), 233-259.

Chen, L., Olhanger, J., and Tang, O. (2014). Manufacturing facility location and sustainability: a literature and research agenda. International Journal of Production Economics 149, 154-163.

Chen, I.J., and Paulraj, A. (2004). Towards a Theory of Supply Chain Management: The Constructs and Measurement. Journal of Operations Management 22(2), 119-150.

Cousins, P.D., Lawson, B., and Squire, B. (2006). Supply chain management: theory and practice, the emergence of an academic discipline? International Journal of Operations and Production Management 26(7), 697-702.

Churchill Jr., G.A. (1979). A Paradigm for Developing Better Measures of Marketing Constructs. Journal of Marketing Research 16(1), 64-73.

Curran, P.J., West, S.G., and Finch, J.F. (1996). The Robustness of Test Statistics to Nonnormality and Specification Error in Confirmatory Factor Analysis. Psychological Methods 1(1), 16-19.

CII-BSG Report, 2012. Re-igniting India's Quest for Manufacturing Leadership. The Boston Consulting Group.

Deif, A.M. (2011). A System Model for Green Manufacturing. Journal of Cleaner Production 19(14), 1553-1559.

Despeisse, M., Ball, P.D., Evans, S., and Levers, A. (2012). Industrial Ecology at Factory Level - a Conceptual Model. Journal of Cleaner Production 31(3-4), 30-39.

Dillman, D. (2007). Mail and Internet Surveys: The Tailored Design Method. New York: Wiley.

DiMaggio, P.J., and Powell, W.W. (1983). The Iron Cage Revisited: Institutional Isomorphism and Collective Rationality in Organizational Fields. American Sociological Review 48(2), 147-160.

Dubey, R., Bag, S., \& Ali, S. S. (2014). Green supply chain practices and its impact on organisational performance: an insight from Indian rubber industry. International Journal of Logistics Systems and Management, 19(1), 20-42. 
Dubey, R., Gunasekaran, A., and Ali, S. S. (2015). Exploring the relationship between leadership, operational practices, institutional pressures and environmental performance: A framework for green supply chain. International Journal of Production Economics 160(2), 120-132.

Dues, C.M., Tan, K.H., and Lim, M. (2013). Green as the New Lean: How to use Lean Practices as a Catalyst to Greening your Supply Chain. Journal of Cleaner Production 40, 93-100.

Farish, M. (2009). Plants That Are Green: Toyota's Lean Manufacturing. Engineering and Technology 4(3), 68-9.

Flynn, B.B., Schroeder, R.C., and Sakakibara, S. (1994). A framework for quality management research and an associated measurement instrument. Journal of Operations Management, 11, 339-366.

Foerstl, K., Azadegan, A., Leppelt, T., and Hartmann, E. (2015). Drivers of supplier sustainability: Moving beyond compliance to commitment. Journal of Supply Chain Management 51(1), 6792.

Fornell, C., and Larcker, D.F. (1981). Evaluating Structural Equation Models with Unobservable Variables and Measurement Error. Journal of Marketing Research 18(1), 39-50.

Franchetti, M., Bedal, K., Ulloa, J., and Grodek, S. (2009). Lean and Green: Industrial Engineering Methods are Natural Stepping Stones to Green Engineering. Industrial Engineer 41(9), 24-29.

Gattiker, T.F., and Carter, C.R. (2010). Understanding project champion's ability to gain intraorganizational commitment for environmental projects. Journal of Operations Management 28(1), 72-85.

Gavronski, I., Klassen, R.D., Vachon, S., and Nascimento, L.F.M. (2011). A resource-based view of green supply management. Transportation Research Part E: Logistics and Transportation Review 47(6), 872-885.

Ghosh, D., and Shah, J. (2012). A comparative analysis of greening policies across supply chain structures. International Journal of Production Economics 135(2), 568-583.

Giannakis, M. (2007). Performance measurement of supplier relationships. Supply Chain Management: An International Journal 12(6), $400-411$.

Gimenez, C., Vaart, T.V.D., and Donk, D.P.V. (2012). Supply chain integration and performance: the moderating effect of supply complexity. International Journal of Operations \& Production Management 32(5), 583-610.

Gimenez, C., and Tachizawa, E.M. (2012). Extending sustainability to suppliers: a systematic literature review. Supply Chain Management: An International Journal 17(5), 531 - 543.

Giovanni, P.D., and V.E. Vinzi. (2012). Covariance versus Component-based Estimates of Performance in Green Supply Chain Management. International Journal of Production Economics 135(2), 907-916.

Giovanni, P.D. (2012). Do internal and external environmental management contribute to the triple bottom line? International Journal of Operations \& Production Management 32(3), 265 $-290$. 
González-Benito, J., and González-Benito, Ó. (2005). Environmental proactivity and business performance: an empirical analysis. Omega 33(1), 1-15.

Govindan, K., Khodaverdi, R., and Jafarian, A. (2013). A fuzzy multi criteria approach for measuring sustainability performance of a supplier based on triple bottom line approach. Journal of Cleaner Production 47, 345-354.

Green Jr, K. W., Zelbst, P. J., Meacham, J., and Bhadauria, V. S. (2012). Green supply chain management practices: impact on performance. Supply Chain Management: An International Journal 17(3), 290-305.

Gunasekaran, A., Irani, Z., Choy, K-L., Filippi, L., and Papadopoulos, T. (2015) Performance measures and metrics in outsourcing decisions: a review for research and applications. International Journal of Production Economics 161, 153-166.

Gunasekaran, A., and Gallear, D., (2012). Special Issue on Sustainable development of manufacturing and services. International Journal of Production Economics 140(1), 1-6.

Gunasekaran, A. and Spalanzani, A. (2012). Sustainable of manufacturing services: Investigation for research and applications. International Journal of Production Economics 140(1), 35-47.

Hair, J.F., Anderson, R.E., Tatham, R.L., and Black, W.C. (1998). Multivariate Data Analysis, Upper Saddle River, NJ: Prentice-Hall.

Hervani, A. A., Helms, M. M., and Sarkis, J. (2005). Performance measurement for green supply chain management. Benchmarking: An International Journal 12(4):330-353.

Hoejmose, S., Brammer, S., and Millington, A. (2012). "Green" supply chain management: The role of trust and top management in B2B and B2C markets. Industrial Marketing Management $41,609-620$

Hollos, D., Blome, C., and Foerstl, K. (2012). Does sustainable supplier cooperation affect performance? Examining implications for the triple bottom line. International Journal of Production Research 50(11), 2968-2986.

Hofer C., Cantor, D.E., and Dai, J. (2012). The Competitive Determinants of a firm's Environmental Activities: Evidence from US Manufacturing Industries. Journal of Operations Management 30(1-2), 69-84.

van Hoof, B., and Lyon, T.P. (2013). Cleaner production in small firms taking part in Mexico's sustainable supplier program. Journal of Cleaner Production 41, 270-282.

Hsu, C.C., Tan, K.C., Zailani, S.H.M., and Jayaraman, V. (2013). Supply chain drivers that foster the development of green initiatives in an emerging economy. International Journal of Operations \& Production Management, 33 (6), 656-688.

Hsu, C.W., and Hu, A.H. (2009). Applying Hazardous Substance Management to Supplier Selection Using Analytic Network Process. Journal of Cleaner Production 17(2), 255-264.

Hudson, L.A., and Ozanne, J.L. (1988). Alternative Ways of Seeking Knowledge in Consumer Research. Journal of Consumer Research 14(4), 508-521. 
Jabbour, C.J.C., and Jabbour, A.B.L.D.S. (2015). Green Human Resource Management and Green Supply Chain Management: linking two emerging agendas. Journal of Cleaner Production, In Press.

Jabbour, A.B.L.D.S., Jabbour, C.J.C., Latan, H., Teixeira, A.A., and de Oliveira, J.H.C. (2014). Quality management, environmental management maturity, green supply chain practices and green performance of Brazilian companies with ISO 14001 certification: Direct and indirect effects. Transportation Research Part E: Logistics and Transportation Review 67, 39-51.

Jabbour, A.B.L.D.S., Jabbour, C.J.C., Sarkis, J., and Govindan, K. (2013).

Brazil's new national policy on solid waste: challenges and opportunities. Clean Technologies and Environmental Policy, 1-3.

Jayaram, J., and Avittathur, B. (2015). Green supply chains: A perspective from an emerging economy. International Journal of Production Economics, 164, 234-244.

Kauppi, K. (2013). Extending the use of Institutional Theory in Operations and Supply Chain Management Research: Review and Research Suggestions. International Journal of Operations \& Production Management 33(10), 13181345.

Kaynak, H. (2003). The Relationship between Total Quality Management Practices and their Effects on Firm Performance. Journal of Operations Management 21(4), 405-435.

Ketokivi, M.A., and Schroeder, R.G. (2004). "Strategic, Structural Contingency and Institutional Explanations in the Adoption of Innovative Manufacturing Practices. Journal of Operations Management 22 (1), 63-89.

Ketokivi, M., and Choi, T. (2014). Renaissance of case research as a scientific method. Journal of Operations Management 32(5), 232-240.

Kitazawa, S., and Sarkis, J. (2000). The relationship between ISO 14001 and continuous source reduction programs. International Journal of Operations \& Production Management 20(2), 225-248.

Ku, C.Y., Chang, C.T., and Ho, H.P. (2010). Global supplier selection using fuzzy analytic hierarchy process and fuzzy goal programming. Quality \& Quantity 44 (4), 623-640.

Kumar, A., Jain, V., and Kumar, S. (2014). A comprehensive environment friendly approach for supplier selection. Omega 42(1), 109-123.

Lambert, D.M., and T.C. Harrington. (1990). Measuring Nonresponse Bias in Customer Service Mail Surveys. Journal of Business Logistics 11(2), 5-25.

Large, R. O., \& Thomsen, C. G. (2011). Drivers of green supply management performance: Evidence from Germany. Journal of Purchasing and Supply Management, 17(3), 176-184.

Law, K.M.Y., and Gunasekaran, A. (2012). Sustainability development in hightech manufacturing firms in Hong Kong: Motivators and readiness. International Journal of Production Economics 137(1), 116-125.

Lee, S. Y., \& Klassen, R. D. (2008). Drivers and enablers that foster environmental management capabilities in small-and medium-sized suppliers in supply chains. Production and Operations Management, 17(6), 573-586. 
Leppelt, T., Foerstl, K., Reuter, C., and Hartmann, E. (2013). Sustainability management beyond organizational boundaries-sustainable supplier relationship management in the chemical industry. Journal of Cleaner Production 56, 94-102.

Liang, H., Saraf, N., Hu, Q., and Xue, Y. (2007). Assimilation of enterprise systems: the effect of institutional pressures and the mediating role of top management. MIS quarterly, 31(1), 5987.

Lightfoot, H., Baines, T., and Smart, P. (2013). The servitization of manufacturing. International Journal of Operations and Productions Management 33(11/12), 1408-1434.

Luthra, S., Kumar, V., Kumar, S. and Haleem, A. (2011). Barriers to Implement Green Supply Chain Management in Automobile Industry using Interpretative Structural Modeling Technique-an Indian Perspective. Journal of Industrial Engineering and Management 4(2), 231-257.

Mandal, A. and Deshmukh, S.G. (1994). Vendor selection using interpretive structural modeling (ISM). International Journal of Operations and Production Management 14(6) 52-59.

Markman, G., and Krause, D. (2014). Special Topic Forum on Theory Building Surrounding Sustainable Supply Chain Management. Journal of Supply Chain Management 50(2), i-ii.

Mathiyazhagan, K., Govindan, K., and Noorul Haq, A. (2014). Pressure analysis for green supply chain management implementation in Indian industries using analytic hierarchy process. International Journal of Production Research 52(1), 188-202.

Mathiyazhagan, K., Govindan, K., Noorul Haq, A., and Geng, Y. (2013). An ISM approach for the barrier analysis in implementing green supply chain management. Journal of Cleaner Production 47, 283-297.

Melnyk, S.A., Narasimhan, R., and DeCampos, H.A. (2014). Supply chain design: issues, challenges, frameworks and solutions. International Journal of Production Research 52(7), 1887-1896.

Merali, Y., Papadopoulos, T., and Nadkarni, T. (2012_. Information systems strategy: Past, present, future? Journal of Strategic Information Systems 21 (2), 125-153.

Meredith, J. (1998). Building operations management theory through case and field research. Journal of operations management 16(4), 441-454.

Mooi, E., and Serstedt, M. (2011). A concise Guide to Market Research. Springer-Verlag, Berlin Hiedelberg.

Muduli, K., Govindan, K., Barve, A., and Geng, Y. (2013). Barriers to green supply chain management in Indian mining industries: A graph theoretic approach. Journal of Cleaner Production 47, 335-344.

Muduli, K., Govindan, K., Barve, A., Kannan, D., and Geng, Y. (2013a). Role of behavioral factors in green supply chain management implementation in Indian mining industries. Resources, Conservation and Recycling, 76(July), 50-60.

Murovec, N., Erker, R.S., and Prodan, I. (2012). Determinants of Environmental Investments: Testing the Structural Model. Journal of Cleaner Production 37, 265-277. 
Nguene, G., Fragnière, E., Kanala, R., Lavigne, D., and Moresino, F. (2011). SOCIO-MARKAL: Integrating energy consumption behavioral changes in the technological optimization framework. Energy for Sustainable Development 15(1), 73-83.

Pagell, M., and Wu, Z. (2009). Building a more complete theory of sustainable supply chain management using case studies of 10 exemplars. Journal of supply chain management 45(2), 37-56.

Pauli, G. (1997). Zero Emissions: The Ultimate Goal of Cleaner Production. Journal of Cleaner Production 5(1/2), 109-113.

Paulraj, A., and de Jong, P. (2011). The effect of ISO 14001 certification announcements on stock performance. International Journal of Operations and Production Management 31(7), 765788.

Pereira-Moliner, J., Claver-Cortes, E., Molina-Azorin, J., and Tari, J. (2012_. Quality Management, Environmental Management and Firm Performance: Direct and Mediating Effects in the Hotel Industry." Journal of Cleaner Production 37, 82-92.

Podsakoff, P.M., MacKenzie, S.B., Lee, J.-Y., and Podsakoff, N.P. (2003). Common Method Biases in Behavioral Research: A Critical Review of the Literature and Recommended Remedies. Journal of Applied Psychology 88, 879-903.

Prajogo, D., Chowdhury, M., Yeung, A.C.L., and Cheng, T.C.E. (2012). The relationship between supplier management and firm's operational performance: A multi-dimensional perspective. International Journal Production Economics 136, 123-130.

Roth, A.V. (2007). Applications of empirical science in manufacturing and service operations. Manufacturing and Service Operations Management 9(4), 353-367.

Rowley, J., and Slack, F. (2004). Conducting a literature review. Management Research News 27 (6), 31-39.

Sarkis, J., Zhu, Q., and Lai, K. (2011). An organizational theoretic review of green supply chain management literature. International Journal of Production Economics 130(1), 1-15.

Schoenherr, T. (2012). The role of environmental management in sustainable business development: a multi-country investigation. International Journal of Production Economics 140(1), 116-128.

Shaw, K., Shankar, R., Yadav, S.S., and Thakur, L.S. (2012). Supplier selection using fuzzy AHP and fuzzy multi-objective linear programming for developing low carbon supply chain. Expert Systems with Applications 39(9), 8182-8192.

Seuring S., Goldbach M., and Koplin J. (2004). Managing time and complexity in supply chains: two cases from the textile industry. International Journal of Integrated Supply Management 1(2), 180-198.

Siaminwe, L., Chinsembu, K., and Syakalima, K. (2005). Policy and Operational Constraints for the Implementation of Cleaner Production. Journal of Cleaner Production 13, 1037-1047.

Sikdar, S.K., and Howell, S.G. (1998). On Developing Cleaner Organic Unit Processes. Journal of Cleaner Production 6(3), 253-259. 
Singh, A., Singh, B., and Dhingra, A.K. (2012). Drivers and Barriers of Green Manufacturing Practices: A Survey of Indian Industries. International Journal of Engineering Sciences 1(1), 519.

Soleimani, H., Seyyed-Esfahani, M., and Govindan, K. (2014). Incorporating risk measures in closed-loop supply chain network design. International Journal of Production Research 52(6), 1843-1867.

Soltani, E., Ahmed, P.K., Liao, Y.Y., and Anosike, P.U. (2014) Qualitative middle-range research in operations management: The need for theorydriven empirical inquiry. International Journal of Operations \& Production Management 34(8), 1003-1027.

Soti, A., Shankar, R., and Kausal, O.P. (2009). Modeling the enablers of Six Sigma using interpreting structural modeling. Journal of Modeling in Management 5(2), 124-141.

Stone, L.J. (2006). Limitations of Cleaner Production Programmes as

Organizational Change Agents. II Leadership, Support, Communication, Involvement and Programme Design. Journal of Cleaner Production 14, 1530.

Strauss, A. and Corbin, J.M. (1990). Basics of qualitative research: Grounded theory procedures and techniques. Sage Publications, Inc.

Subramanian, N., \& Gunasekaran, A. (2015). Cleaner supply-chain management practices for twenty-first-century organizational competitiveness: Practice-performance framework and research propositions. International Journal of Production Economics, 164, 216-233.

Sushil (2012). Interpreting the Interpretive Structural Model. Global Journal of Flexible Systems Management 13(2), 87-106.

Tate, W.L., Ellram, L.M., and Kirchoff, J.F. (2010). Corporate social responsibility reports: a thematic analysis related to supply chain management. Journal of Supply Chain Management, 46(1), 19-44.

Testa, F., and Iraldo, F. (2010). Shadows and Lights of GSCM (Green Supply Chain Management): Determinants and Effects of these Practices Based on a Multinational Study. Journal of Cleaner Production 18(10/11), 953-962.

Thakkar, J., Kanda, A., and Deshmukh, S.G. (2008). Interpretive Structural Modeling (ISM) of ITenablers for Indian Manufacturing SMEs. Information Management and Computer Security 16(2), 113-136.

Tranfield, D., Denyer, D. and Smart, P. (2003). Towards a methodology for developing evidenceinformed management knowledge by means of a systematic review. British Journal of Management 14(3), 207-222.

Tsoulfas, G.T. and Pappis, C.P. (2006). Environmental Principles Applicable To Supply Chains Design and Operation. Journal of Cleaner Production 14(1), 1593-1602.

Vachon, S., and Klassen, R.D. (2006). Green Project Partnership in the Supply Chain: The Case of the Package Printing Industry. Journal of Cleaner Production 14(6/7), 661-671. 
Wagner, M., and Schaltegger, S. (2004). The Effect of Corporate Strategy Choice and Environmental Performance on Competitiveness and Economic Performance: An Empirical Study of EU Manufacturing. European Management Journal 22(5), 557-572.

Wang, M., Jie, F., and Abareshi, A. (2014). The Measurement Model of Supply Chain Uncertainty and Risk in the Australian Courier Industry. Operations and Supply Chain Management 7(3), 89-96.

Warfield, J.W. (1974). Developing interconnected matrices in structural modeling. IEEE transcript on systems, men and cybernetics, 4(1), 51-81.

Whetten, D.A. (1989). What Constitutes a Theoretical Contribution? Academy of Management Review 14(4), 490-495

Yusuf, Y.Y., Gunasekaran, A., Musa, A., El-Berishy, N.M., Abubakar, T., and Ambursa, H.M., (2013). The UK oil and gas supply chains: An empirical analysis of adoption of sustainable measures and performance outcomes. International Journal of Production Economics 146(2), 501-514.

Zailani, S., Jeyaraman, K., Vengadasan, G., and Premkumar, R. (2012). Sustainable Supply Chain Management (SSCM) in Malaysia: a survey. International Journal of Production Economics 140 (1), 330-340.

Zhang, F., Rio, M., Allais, R., Zwo Linski, P., Carrillo, T.R., Roucoules, L., Mercier-Laurent, E., and Buclet, N. (2013). Toward a Systematic Navigation Framework to Integrate Sustainable Development into the Company. Journal of Cleaner Production 54(1), 199-214.

Zhang, B., and Wang, Z. (2014). Inter-firm collaborations on carbon emission reduction within industrial chains in China: Practices, drivers and effects on firms' performances. Energy Economics 42, 115-131.

Zhu, Q., Sarkis, J., and Lai, K. (2008). Green Supply Chain Management Implications for Closing the Loop. Transportation Research Part E 44(1), 1-8.

Zhu, Q., Sarkis, J., Lai, K., and Geng, Y. (2008). The Role of Organizational Size in the Adoption of Green Supply Chain Management Practices in China.

Corporate Social Responsibility and Environment Management 15(6), 322- 337.

Zhu, Q., and Sarkis, J. (2007). The Moderating Effects of Institutional Pressures on Emergent Green Supply Chain Practices and Performance.

International Journal of Production Research 45(18-19), 4333-43355.

Zhu, Q., and Sarkis, J., (2004). Relationships between operational practices and performance among early adopters of green supply chain management practices in Chinese manufacturing enterprises. Journal of Operations Management 22, 265-289.

Zhu, Q., and Sarkis, J. (2006). An inter-sectoral comparison of green supply chain management in China: drivers and practices. Journal of Cleaner Production 14(5), 472-486. 
Zhu, Q., Sarkis, J., and Geng, Y. (2005). Green Supply Chain Management in China: Pressure, Practices and Performance. International Journal of Operations and Production Management 25(5), 449-468.

Zhu, Q., Sarkis, J., and Lai, K.H. (2012). Examining the Effects of Green Supply Chain Management Practices and their Mediations on Performance Improvements. International Journal of Production Research 50(5), 13771394.

Zhu, Q., and Geng, Y. (2013). Drivers and barriers of extended supply chain practices for energy saving and emission reduction among Chinese manufacturers. Journal of Cleaner Production 40, 6-12.

Zhu, Q., Sarkis, J., Cordeiro, J.J., and Lai, K. (2008). Firm-level correlates of emergent green supply chain management practices in the Chinese context. Omega 36(4), 577-591.

Zsidisin, G., Melnyk, S., and Ragatz, G. (2005). An Institutional Theory Perspective of Business Continuity Planning for Purchasing and Supply Management. International Journal of Production Research 43(16), 3401-20. 
